\title{
TGF- $\beta$ Family Signaling in Tumor Suppression and Cancer Progression
}

\author{
Joan Seoane ${ }^{1,2,4}$ and Roger R. Gomis s,3,4 $^{2,3}$ \\ ${ }^{1}$ Translational Research Program, Vall d'Hebron Institute of Oncology, 08035 Barcelona, Spain \\ ${ }^{2}$ Institució Catalana de Recerca i Estudis Avançats (ICREA), 08010 Barcelona, Spain \\ ${ }^{3}$ Oncology Program, Institute for Research in Biomedicine (IRB Barcelona), The Barcelona Institute \\ of Science and Technology, 08028 Barcelona, Spain \\ Correspondence: jseoane@vhio.net; roger.gomis@irbbarcelona.org
}

Transforming growth factor- $\beta$ (TGF- $\beta$ ) induces a pleiotropic pathway that is modulated by the cellular context and its integration with other signaling pathways. In cancer, the pleiotropic reaction to TGF- $\beta$ leads to a diverse and varied set of gene responses that range from cytostatic and apoptotic tumor-suppressive ones in early stage tumors, to proliferative, invasive, angiogenic, and oncogenic ones in advanced cancer. Here, we review the knowledge accumulated about the molecular mechanisms involved in the dual response to TGF- $\beta$ in cancer, and how tumor cells evolve to evade the tumor-suppressive responses of this signaling pathway and then hijack the signal, converting it into an oncogenic factor. Only through the detailed study of this complexity can the suitability of the TGF- $\beta$ pathway as a therapeutic target against cancer be evaluated.

$\mathrm{O}$ ne of the hallmarks of the transforming growth factor- $\beta$ (TGF- $\beta$ ) pathway is its pleiotropic nature. Exerting a wide range of functions, TGF- $\beta$ is a critical cytokine in embryogenesis and tissue homeostasis. TGF- $\beta$ can induce a large and diverse set of responses, ranging from the induction of tissue growth and morphogenesis in the embryo to activation of cellular cytostatic and death processes in epithelial cells. The nature of the pleiotropic response to TGF- $\beta$ is determined by the cellular context and the integration of the TGF- $\beta$ pathway with other signaling cascades.

Paradoxically, and within the concept of TGF- $\beta$ pleiotropic responses, this cytokine in- hibits cell proliferation and stimulates differentiation in normal cells, thus acting as a tumorsuppressor factor (Roberts and Wakefield 2003; Bierie and Moses 2006). In contrast, in advanced cancer, it induces tumor progression and metastasis, thus serving as an oncogenic factor. Tumor cells escape the growth inhibitory effects of TGF- $\beta$ by accumulating mutations in components of the TGF- $\beta$ signaling cascade or by selectively impairing the antitumoral response. In the latter case, cancer cells hijack several TGF- $\beta$-initiated pathways to their benefit, turning TGF- $\beta$ into an oncogenic factor that induces angiogenesis, invasion, immunosuppression, and self-renewal of cancer-initiating

\footnotetext{
${ }^{4}$ These authors contributed equally to this work.

Editors: Rik Derynck and Kohei Miyazono

Additional Perspectives on The Biology of the TGF- $\beta$ Family available at www.cshperspectives.org

Copyright (C) 2017 Cold Spring Harbor Laboratory Press; all rights reserved; doi: 10.1101/cshperspect.a022277

Cite this article as Cold Spring Harb Perspect Biol 2017;9:a022277
} 
cells. Researchers have explored the mechanisms underlying this phenomenon, revealing the biological complexity arising from the integration of various layers of signaling mediators, cell type, and cell function specificity, as well as stromal contribution. Here, we review the knowledge of the mechanisms involved in the transformation of the TGF- $\beta$ pathway from a tumor suppressor to a tumor promoter factor and discuss the implication of this process for understanding cancer biology and treatment (Fig. 1).

\section{THE NATURE OF A PLEIOTROPIC PATHWAY}

The signaling pathway that conveys TGF- $\beta$ inputs from membrane receptors to cellular responses has started to be clarified (Fig. 2). TGF- $\beta$ binds to receptors at the cell surface, forming a bi-dimeric receptor complex of the TGF- $\beta$ type I receptor (T $\beta$ RI, also known as ALK-5) and TGF- $\beta$ type II receptor (T $\beta$ RII) (Derynck and Zhang 2003; Shi and Massagué 2003), and causes activation of TGF- $\beta$ receptor

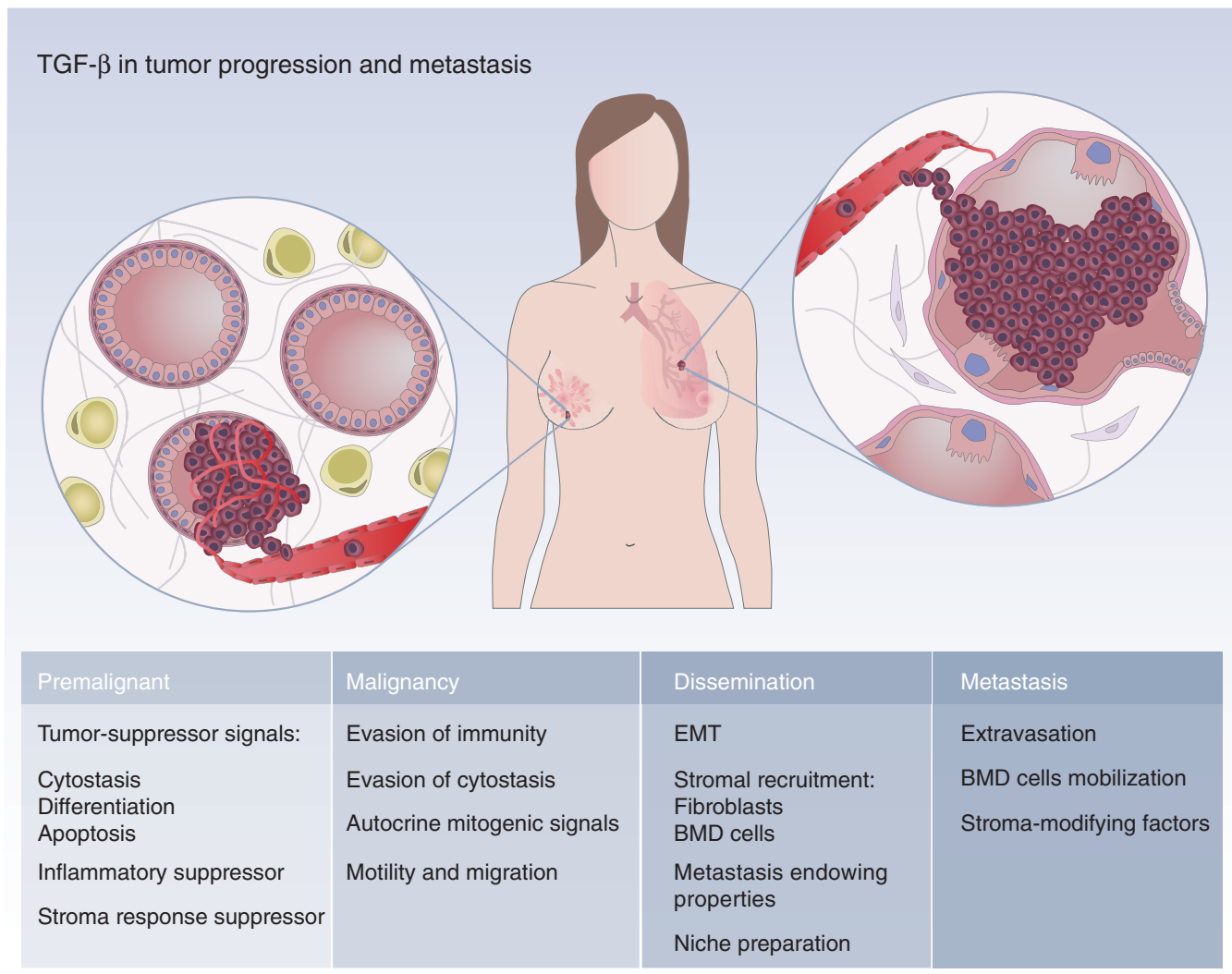

Figure 1. Transforming growth factor $\beta$ (TGF- $\beta$ ) in tumor progression and metastasis. TGF- $\beta$ limits the growth of normal epithelium and premalignant lesions. Loss of the cytostatic response to TGF- $\beta$ can occur by mutations in or loss of TGF- $\beta$ receptors, Smads, or by specific loss of mediators of the TGF- $\beta$ cytostatic responses. In addition, tumors evade the immune response and increase autocrine mitogenic signals and motility and migration during malignancy. Tumor cells that have lost the cytostatic response may undergo epithelial-tomesenchymal transition (EMT) in response to TGF- $\beta$ and become more invasive. Concurrently, these cells may use TGF- $\beta$ to evade the immunosuppressive environment and induce angiogenesis and systemic dissemination. Finally, adherence of tumor cells to the endothelium and/or extravasation of tumor cells at sites of metastasis, such as lung, can be enhanced by TGF- $\beta$ signaling. Similarly, stroma-modifying factors, such as those that promote osteolytic bone metastasis by breast cancer cells, are driven by TGF- $\beta$ signaling. BMD, bone marrowderived. 


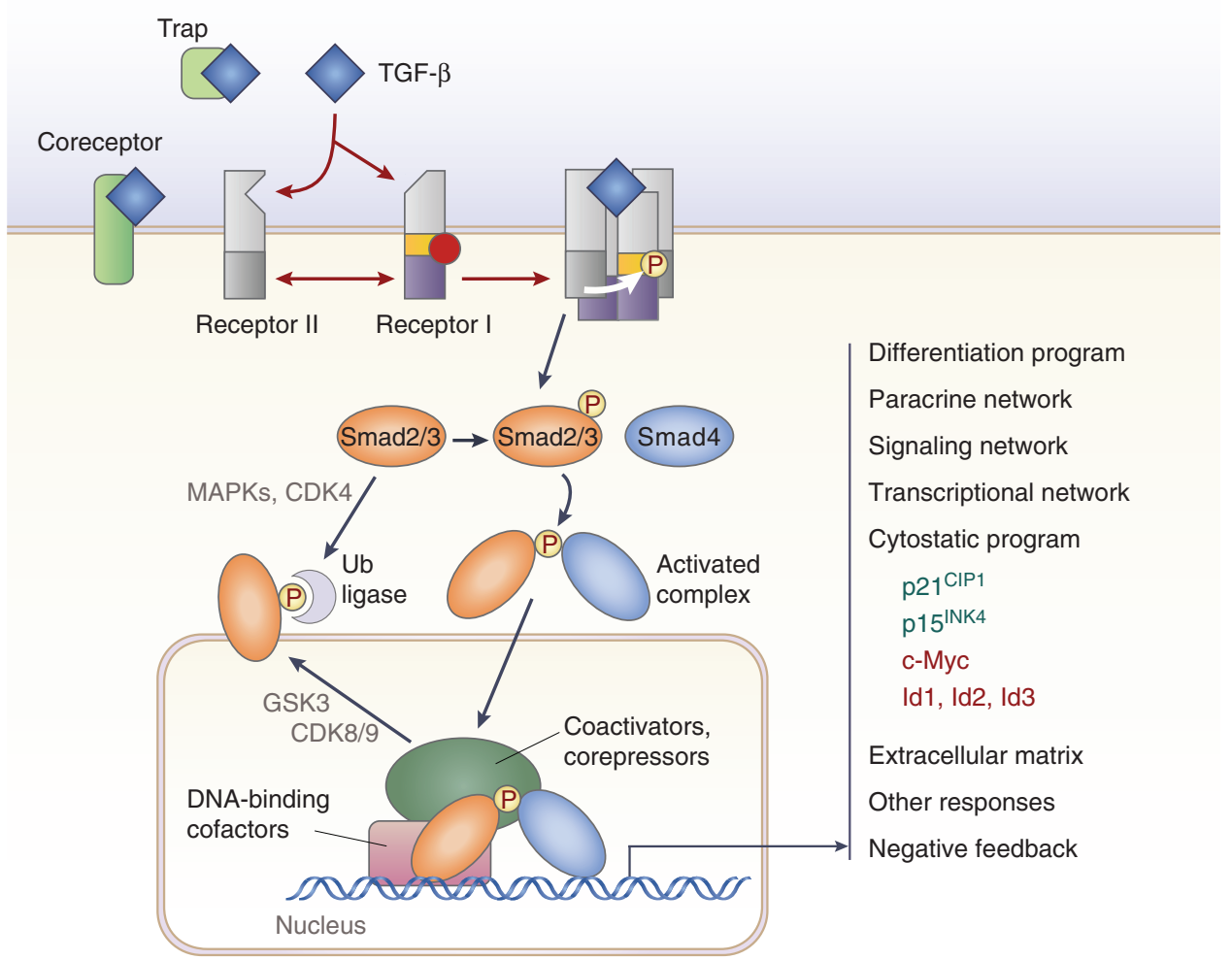

Figure 2 . The transforming growth factor $\beta$ (TGF- $\beta$ )-induced Smad signaling pathway. TGF- $\beta$ binds to the type II receptor and recruits the type I receptor, whereby the type II receptor phosphorylates and activates type I receptor. The type I receptor, in turn, phosphorylates receptor-activated Smads (Smad2 and Smad3) at the carboxy-terminal SXS motif, which results in release of these Smads from the receptor complex in the cytoplasm and triggers their translocation into the nucleus. Smad4 acts as a common partner of activated Smads to help execute their function. Smad proteins continuously undergo nucleocytoplasmic shuttling and interact with nuclear pore complexes. Once in the nucleus, activated Smad proteins form complexes that regulate target gene transcription, generating hundreds of early gene responses. Mechanisms of phosphorylation and polyubiquitylation account for the signal termination of the activated Smads. On the right, TGF- $\beta$ target genes in epithelial cells are grouped on the basis of their biological responses. Highlighted in red are gene responses repressed by TGF- $\beta$, and in green are gene responses induced by TGF- $\beta$. These are central for the cytostatic program induced by TGF- $\beta$.

transmembrane dual specificity kinase (Attisano et al. 1992; Lin et al. 1992; Franzén et al. 1993; Tsuchida et al. 1993; Takumi et al. 1995; Luo and Lodish 1997). On ligand binding, the type II receptor phosphorylates serine and threonine residues in the type I receptor, which subsequently propagates the signal through Smad activation (Wrana et al. 1994). Phosphorylation switches this region from serving as a docking site for an inhibitor, FKBP12, to a docking site for its various substrates, including the Smad family of transcription factors (Huse et al. $1999,2001)$. In the absence of phosphorylation, Smads are transcriptionally inert but undergo constant nucleocytoplasmic shuttling through the nuclear pore complex (Xu et al. 2003; Chen et al. 2005a; Schmierer and Hill 2005; Varelas et al. 2008). Receptor-mediated phosphorylation of Smads occurs at their carboxyterminal regions and induces the accumulation of receptor-activated Smad (R-Smad) proteins in the nucleus (Hoodless et al. 1996; Liu et al. 
1996; Kretzschmar et al. 1997). The phosphorylated motif of the R-Smad generates a docking site for Smad4 (Wu et al. 2000, 2001), which is not a receptor substrate but an important component of the resulting R-Smad transcriptional complexes (Lagna et al. 1996; Shi and Massagué 2003).

Not all responses to TGF- $\beta$ are Smad-dependent, thus further increasing the level of complexity. TGF- $\beta$ has been shown to activate other mediators, such as the extracellular signalregulated kinase (Erk), c-Jun amino-terminal kinase (JNK) and p38 mitogen-activated protein kinases (MAPKs), phosphatidylinosititol 3-kinase (PI3K), PP2A phosphatases, Rho family members, and many others (reviewed in Derynck and Zhang 2003; Derynck et al. 2014). These alternative pathways are activated by TGF- $\beta$ in a cell-type-dependent manner, and their biochemical associations with the activated receptors are variable. Not surprisingly, the expansion of TGF- $\beta$ signaling beyond the canonical pathway implies yet another layer of diversity and thus supports the pleiotropic responses. TGF- $\beta$-induced epithelial-to-mesenchymal transition (EMT) involves Par6 activation and ubiquitin-mediated degradation of RhoA at tight junctions (Ozdamar et al. 2005), as well as TGF- $\beta$-induced Akt activation, thus causing mTOR activation and enhanced protein synthesis (Lamouille et al. 2012; Fruman and Rommel 2014). Additionally, ShcA phosphorylation by the T $\beta R I$ receptor causes activation of Erk1/2 MAPK signaling, whereas activation of p38 MAPK and/or JNK are caused by the recruitment of the E3 ubiquitin ligases TRAF4 or TRAF6 to the TGF- $\beta$ receptor complex, which, in turn, causes TAK1 kinase activation (Sorrentino et al. 2008). These inputs may directly regulate the stability and activities of Smads (Zhang 2009; Mu et al. 2012). Thus, these signals instruct nontranscription changes and also cooperate with Smad-mediated gene expression, tuning the outcome of the TGF- $\beta$ signal (Derynck et al. 2014).

R-Smad activation typically leads to the formation of a complex with Smad4 and hundreds of immediate gene activation or repression responses (Feng et al. 1998; Zhang et al. 1998).
Smad proteins consist of a Mad homology (MH) 1 and an MH2 domain connected by a linker region (Derynck and Zhang 2003). The former is mainly responsible for DNA binding (Shi et al. 1998), whereas the latter establishes contacts with anchors for cytoplasmic retention (Wu et al. 2000), receptors for activation (Huse et al. 2001), and nucleoporins for nucleocytoplasmic translocation (Xu et al. 2002), and both domains partner Smads and other nuclear transcription factors for the assembly of transcriptional complexes (Wu et al. 2001). R-SmadSmad4 complexes have DNA-binding activity; however, they must associate with other cofactors to achieve DNA interaction with high affinity and selectivity. To date, many partners have been reported among transcription factor families, including the AP1, forkhead, basic helixloop-helix (bHLH), and zinc finger transcription factors (Feng and Derynck 2005). Each complex is tailored for a particular regulatory DNA-binding region and is thus responsible for the expression of a given set of genes. Activated Smad complexes also mobilize coactivators and corepressors, as well as chromatin remodeling factors. Collectively, permutations and variations of these various players explain how and why a single TGF- $\beta$ stimulus can activate or repress several genes at a time.

Gene response termination is also regulated at the level of Smad complexes (Fig. 2). It has been proposed that PPM1A protein phosphatase terminates R-Smad carboxy-terminal phosphorylation, thus stimulating the rapid exclusion of activated Smads from the nuclei (Lin et al. 2006). There is also evidence that R-Smads undergo selective ubiquitin-mediated degradation (Lo and Massague 1999). The involvement of Smad ubiquitylation regulatory factors (Smurfs) in this process and the manner in which phosphorylated R-Smads are recognized for degradation have become clearer. Smads are phosphorylated in the linker region by cyclindependent kinase (CDK) 8 and CDK9 (Alarcón et al. 2009). This event attracts factors that support the transcriptional function and/or the phosphorylation of the linker region by glycogen synthase kinase 3 (GSK3) (Fuentealba et al. 2007; Sapkota et al. 2007). These resulting new 
binding sites support the recruitment of Smurf E3 ubiquitin ligase or NEDD4L, which target Smad proteins for degradation through polyubiquitylation and proteasome degradation (Gao et al. 2009). Similarly, SCP1-3 protein phosphatases may also account for Smad1 carboxy-terminal and linker region dephosphorylation (Sapkota et al. 2006). Cellular stress, growth factors, inflammatory cytokines, and other stimuli, mediated by MAPK signaling pathways, are responsible for the phosphorylation of the linker region. This event is proposed, among other functions, to expose the binding site of Smurf1 E3 ubiquitin ligase, as modeled in Smad1 (Sapkota et al. 2007). Similarly, the phosphorylation of the linker regions of Smad2 and Smad3 may enhance degradation by other ubiquitin ligases (Aragón et al. 2011; Macias et al. 2015).

Furthermore, TGF- $\beta$ signaling is negatively controlled by a feedback loop mediated by the inhibitory Smads — namely, Smad6 and Smad7. Smad6 and Smad 4 compete for Smad1 binding, whereas Smad7 and Smad6 recruit Smurf to inactivate signaling at the TGF- $\beta$ and bone morphogenetic protein (BMP) receptor level (Goto et al. 2007). Smurf-mediated polyubiquitylation targets the receptors for degradation by the proteasome. Interestingly, the deubiquitylating enzymes USP15 and USP4 have been described to counteract the function of Smurfs and to promote receptor stabilization (Eichhorn et al. 2012; Zhang et al. 2012). The physiological levels of TGF- $\beta$ receptors are determined by the balance between Smurfs and USP15 and/or USP4. The transcriptional repressors c-Ski and SnoN (Ski-like) can also directly inhibit the transcriptional function of Smads (Luo et al. 1999; Stroschein et al. 1999; Zhu et al. 2007). Additionally, other transcriptional repressors encoded by chimeric genes (AML1/EVI-1 $\mathrm{t}(3,21)$ or AML1/ETO $\mathrm{t}(8,21)$ ) interact with Smad3 (Letterio 2005). Beyond the main components of the Smad signaling pathway, several other actors have been identified that stringently regulate the activity of each step of this powerful signaling process (for review, see Massagué 2012).

Given the large set of transcription factors that interact with Smads and the broad set of genes regulated, the TGF- $\beta$ response is pleiotropic, showing various levels of coordination and subjected to context dependence. The various structural Smad motifs facilitate interactions with a wide spectrum of partners. Analogously, each complex arrangement shares specific enhancer element configurations at the DNAbinding level. Thus, within the magnitude of the TGF- $\beta$ response, these common transcriptional regulatory elements define synexpression groups of genes that are coordinately regulated (Niehrs and Pollet 1999; Gomis et al. 2006a). Finally, distinct cell types and contexts define the availability of Smad partners, thus limiting the TGF- $\beta$ response to specific cellular scenarios. This operating procedure supports the ample pleiotropic responsiveness of TGF- $\beta$ and highlights the devastating consequences of its misuse in cancer.

\section{THE TUMOR-SUPPRESSIVE RESPONSE OF TGF- $\beta$}

TGF- $\beta$ has a crucial role in tissue homeostasis. In particular, in normal epithelial cells, this growth factor can induce a potent antiproliferative response and promote cell differentiation and apoptosis. These responses make TGF- $\beta$ a tumor-suppressive factor in early stage tumors. Substantial attention has been directed to the molecular mechanisms involved in the antioncogenic effect of TGF- $\beta$.

\section{The Cytostatic Program}

TGF- $\beta$ inhibits the progression of cell-cycle phase $G_{1}$ through two sets of events, namely, the induction of expression of CDK inhibitors and the suppression of $\mathrm{c}-\mathrm{Myc}$ expression (Fig. $3)$. In epithelial cells, TGF- $\beta$ induces the expression of the CDK inhibitor $\mathrm{p} 15^{\mathrm{INK} 4 \mathrm{~b}}$, which inhibits the formation of cyclin D complexes with CDK4 or CDK6, and of p21 ${ }^{\mathrm{CIP} 1}$, which inhibits the formation of cyclin E or cyclin A complexes with CDK2. The Smad3-Smad4 complexes associate with FoxO transcription factors to target the promoters of the $C D K N 2 B$ gene, which encodes $\mathrm{p} 15^{\mathrm{INK} 4 \mathrm{~b}}$, and of CDKN1A, which encodes $\mathrm{p} 21^{\mathrm{CIP} 1}$, for transcriptional activation 


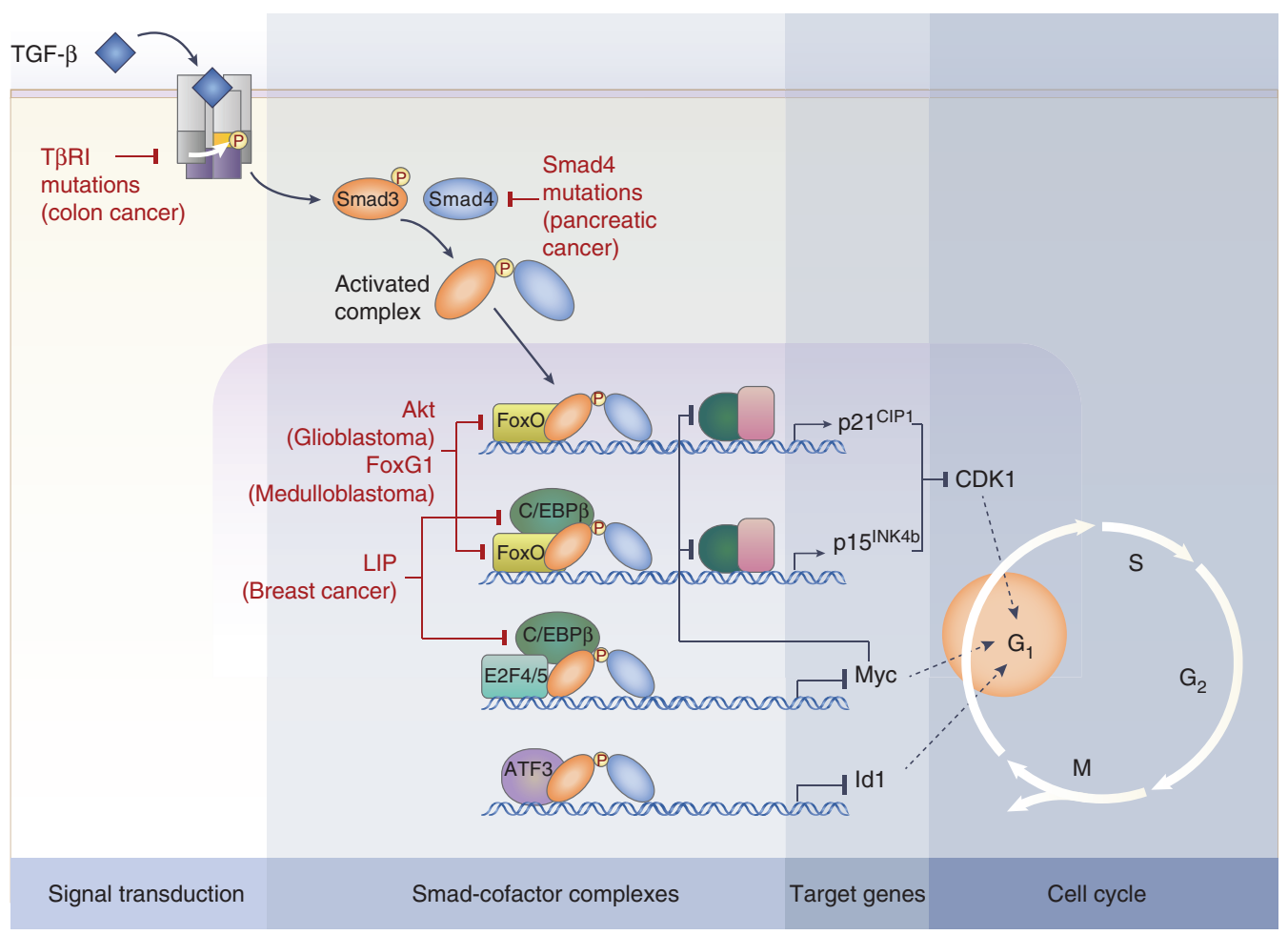

Figure 3. The transforming growth factor $\beta$ (TGF- $\beta$ )-induced transcriptional program and its alterations in cancer. The diagram depicts mutations or alterations that occur in genes that encode mediators of the TGF- $\beta$ signaling pathway in distinct types of human cancers. Shown are the transcriptional components underlying the principal TGF- $\beta$ cytostatic responses in epithelial cells. Indicated in red are the targets of alterations present in distinct types of human cancers converging on the TGF- $\beta$ target genes that mediate cell cycle arrest.

(Seoane et al. 2001, 2004; Gomis et al. 2006a). The induction of these genes also requires the transcription factor Sp1 (Pardali et al. 2000). Another CDK inhibitor, p2 $7^{\text {Kip } 1}$, is mobilized from an inactive state bound to cyclin DCDK4 to an active state that is displaced from these complexes by $\mathrm{p} 15^{\mathrm{INK} 4 \mathrm{~b}}$ to target the complexes of cyclin E or cyclin A with CDK2. TGF- $\beta$ stimulates the expression of $\mathrm{p}^{\mathrm{CIP} 1}$ in $\mathrm{T}$ cells (Wolfraim et al. 2004), $\mathrm{p}^{\mathrm{Kip} 2}$ in hematopoietic stem/progenitor cells (Scandura et al. 2004), and $\mathrm{p} 15^{\mathrm{INK} 4 \mathrm{~b}}$ and $\mathrm{p} 21^{\mathrm{CIP} 1}$ in astrocytes and neural progenitor cells (Seoane et al. 2004). Thus, the particular CDK inhibitors involved in the cytostatic response to TGF- $\beta$ depend on the cell type and context.

c-Myc is a key transcriptional inducer of cell growth and division. In keratinocytes and mammary epithelial cells, down-regulation of $M y c$ expression is mediated by a TGF- $\beta$-induced protein complex containing the Smad3-Smad4 complex, and the transcription factors p107, E2F4 or E2F5, and CCAAT/enhancer binding protein $\beta(\mathrm{C} / \mathrm{EBP} \beta)$ (Chen et al. 2002; Gomis et al. 2006b). The complex of Smad 3 and Smad4 with E2F4 or E2F5 recognizes a proximal element in the $M y c$ promoter, and p107 is thought to recruit corepressors. Interestingly, C/EBP $\beta$ is required for the repression of $M y c$ expression by this complex and for activation of $\mathrm{p} 15^{\text {INK4b }} \mathrm{ex}-$ pression by a Smad3-Smad4-FoxO complex (Gomis et al. 2006a). Thus, C/EBP $\beta$ coordinates the responses of the genes encoding $\mathrm{p} 15^{\mathrm{INK} 4 \mathrm{~b}}$ and $\mathrm{c}-\mathrm{Myc}$ to TGF- $\beta$. Additional coordination is provided by the transcription factor Myc-interacting $\mathrm{Zn}$ finger protein-1 (Miz-1), which, in proliferating cells, recruits c-Myc as a repressor to the transcriptional start regions of the 
TGF- $\beta$ Signaling and Cancer

CDKN2B and CDKN1A promoters (Seoane et al. 2001, 2002; Staller et al. 2001). As cotransducers of Smad signals, FoxO, E2F4 or E2F5, and $\mathrm{C} / \mathrm{EBP} \beta$ integrate multiple inputs into the TGF- $\beta$ cytostatic program.

Smad-independent pathways downstream from TGF- $\beta$ have been also implicated in the antiproliferative response to TGF- $\beta$ (Derynck and Zhang 2003). For example, TGF- $\beta$ induces the dephosphorylation of $\mathrm{p} 70^{\mathrm{S} 6 \mathrm{~K}}$ by PP2A, thus leading to cell cycle arrest (Petritsch et al. 2000).

\section{Effects on Cell Differentiation}

In some cases, TGF- $\beta$ and other members of its family may influence cell differentiation. Through Smad-mediated transcriptional repression or activation of various genes, TGF- $\beta$ signaling may cause changes in cellular differentiation. TGF- $\beta$ promotes the differentiation of mesenchymal precursors into fibroblasts and myofibroblasts at the expense of adipocyte, myocyte, and osteoblast differentiation fates (Derynck and Akhurst 2007). TGF- $\beta$ also regulates differentiation by controlling the expression of Id proteins (inhibitor of differentiation/DNA binding), which inhibit some differentiation pathways by interfering with pro-differentiation bHLH transcription factors (Ruzinova and Benezra 2003). In epithelial and endothelial cells in culture, BMP stimulates $I d 1$ expression and TGF- $\beta$ represses it (Korchynskyi and ten Dijke 2002; Kang et al. 2003a). BMP-induced binding of Smad1 to the $I d 1$ promoter supports transcriptional activation, whereas TGF- $\beta$ signaling through Smad3 induces the expression of the repressor activating transcription factor 3 (ATF3), which is then recruited by Smad3 to the $I d 1$ promoter and represses $I d 1$ expression (Kang et al. 2003a). Id1 enhances Ras-driven mammary tumorigenesis in mice by bypassing senescence (Swarbrick et al. 2008). In a xenograft model using a Ras-transformed human breast epithelial cell line, TGF- $\beta$ down-regulates $I d 1$, thereby suppressing tumor formation by these cells and imposing a less proliferative phenotype (Tang et al. 2007). These findings suggest that Id1 repression mediates cell differentiation as a tumor-suppressive response to TGF- $\beta$.

\section{Induction of Apoptosis}

In addition to the regulation of the cell cycle and cell differentiation, TGF- $\beta$ can trigger apoptosis. Mechanisms of TGF- $\beta$-induced apoptosis include an increase in the expression of deathassociated protein kinase DAPK in hepatoma cells (Jang et al. 2002), the expression of the signaling factor GADD $45 \beta$ (growth arrest and DNA damage $45 \beta$ ) in hepatocytes (Takekawa et al. 2002), and the activation of death receptor FAS and binding of the proapoptotic effector $\mathrm{Bim}$ to $\mathrm{Bcl}-2$ and $\mathrm{Bcl}-\mathrm{X}_{\mathrm{L}}$ in gastric carcinoma cell lines (Ohgushi et al. 2005). In addition, Smad interactions with the p38 MAPK activator DAXX have also been proposed to mediate the proapoptotic effects of this growth factor (Perlman et al. 2001). TGF- $\beta$ promotes apoptosis in hepatocytes and B lymphocytes through Smad3-dependent transcription of the gene encoding phosphatase MKP2, which enhances the proapoptotic effect of the Bcl-2 family member Bim (Ramesh et al. 2008). Interestingly, TGF- $\beta$ inhibits the expression of prosurvival protein survivin, as well as the activity of Akt in colon cancer cells, thus leading to apoptosis (Wang et al. 2008). Moreover, it has been shown that the TGF- $\beta$-Smad pathway, in cooperation with the transcription factors $\mathrm{Rb}$ and E2F4, suppresses survivin expression in prostate epithelial cells (Yang et al. 2008).

In addition to the Smad-dependent responses, TGF- $\beta$ can induce apoptosis by the TRAF6-TAK1-JNK/p38 pathway in some cell types. The E3 ligase TRAF6 was found to have a fundamental role in TGF- $\beta$-induced apoptosis (Sorrentino et al. 2008; Yamashita et al. 2008). TRAF6 binds constitutively to a consensus binding site in T $\beta R I$. Ligand-dependent oligomerization of the T $\beta R I I-T \beta R I$ complex leads to autoubiquitylation of TRAF6, and active TRAF6 subsequently causes polyubiquitylation of TAK1, which promotes its kinase activity. Activated TAK1 then phosphorylates and activates MKK3 or MKK6, which in turn activates p38 MAPK, thereby leading to apoptosis (Yamaguchi et al. 1995; Shibuya et al. 1996). Smad7 acts as a scaffolding protein to facilitate the activation of this MAP kinase cascade (Sor- 
rentino et al. 2008; Yamashita et al. 2008). Some of the proapoptotic effects of TGF- $\beta$ can be linked to the tumor suppressor p53 (Zhang et al. 2006), which in turn is regulated by p38 MAPK and Smads. Interestingly, in hepatocytes, TGF- $\beta$ induces cell death through reactive oxygen species (ROS) production (Sanchez et al. 1996). TGF- $\beta$ induces ROS production by repressing the expression of antioxidant genes or by activating the expression of NADPH oxidase (Nox) (Franklin et al. 2003; Herrera et al. 2004). TGF- $\beta$-induced ROS production can promote apoptosis through a mitochondrial-dependent pathway, at least in part through the modulation of various members of the Bcl-2 family (Ramjaun et al. 2007).

Tumor Suppression through Paracrine Signals In addition to its direct growth-inhibitory effects on target cells, TGF- $\beta$ can restrict epithelial cell proliferation and tumor formation by blocking the production of paracrine factors in stromal fibroblasts and inflammatory cells. The expression of a transgene encoding a dominantnegative T $\beta$ RII receptor in the mammary stroma increases the lateral branching of adjacent mammary ducts. Mice with a targeted deletion of $\mathrm{Tg} f b r 2$ in fibroblasts of the prostate and forestomach show hyperplasia of the adjacent epithelia with progression to prostatic intraepithelial neoplasia and gastric squamous carcinoma, respectively (Bhowmick et al. 2004). These effects are accompanied by elevated expression of hepatocyte growth factor (HGF) in the Tgfbr2-defective fibroblasts and activation of the HGF receptor c-Met in adjacent epithelial cells (Bhowmick et al. 2004). By constraining the expression of mitogenic factors in stromal fibroblasts, TGF- $\beta$ limits the paracrine stimulation of epithelial proliferation and suppresses tumor development.

\section{ESCAPING THE TUMOR-SUPPRESSIVE EFFECT OF TGF- $\beta$}

During tumor progression, tumor cells tend to escape the tumor-suppressive responses to TGF- $\beta$ in the same way as they evade the action of other tumor suppressors, such as the p53 pathway. The evasion of cytostasis and other TGF- $\beta$-related homeostatic functions confers a strong selective advantage in malignancies (Seoane 2006). In this regard, tumor cells elude the tumor-suppressive effect of TGF- $\beta$ through various mechanisms that have come to light.

In some cases, tumor cells acquire somatic mutations or epigenetic silencing in genes encoding components of the TGF- $\beta$-Smad signal transduction pathway (Smads and TGF- $\beta$ receptors) so that they escape the antitumoral function of this cytokine (Fig. 3). In many other tumors, the components of the TGF- $\beta$ signal transduction pathway are not affected, but cells become specifically resistant to the antiproliferative response to TGF- $\beta$ (Fig. 3). Mutational inactivation of genes encoding core pathway components occurs in large subsets of colorectal, pancreatic, ovarian, gastric, and head and neck carcinomas. However, in breast and prostate cancers, gliomas, melanomas, and hematopoietic neoplasias, the cytostatic program of this cytokine is selectively impaired.

Genetic and Epigenetic Alterations in Components of the TGF- $\beta$ Pathway

\section{The Receptor Complex}

Colon cancers with microsatellite instability (MSI) consistently accumulate replication errors in the T $\beta$ RII gene TGFBR2. This pathological condition is caused by mutations in genes involved in the replication mismatch repair machinery, and associated with high $\mathrm{CpG}$ island methylation phenotype (Markowitz et al. 1995). Insertion or deletion of adenines in a 10-bp polyadenine track in the T $\beta$ RII coding sequence are common in gastric, colorectal, biliary, and lung adenocarcinomas, causing the expression of a truncated, inactive receptor (Markowitz et al. 1995; Ogino et al. 2007; Shima et al. 2011). When these alterations occur, the second TGFBR2 allele is subsequently inactivated (Massagué 2008). Analogous alterations in the TGFBR2 gene occur in gastric tumors and gliomas (Izumoto et al. 1997) and in a fraction of microsatellite-stable colorectal tumors with 
inherited mutations in mismatch repair genes. In the latter case, the mutations generally affect the TRRII kinase domain (Grady et al. 1999). Interestingly, breast and endometrial tumors with MSI do not accumulate TGFBR2 mutations. Frameshift, missense, or hypomorphic mutations in the TGFBR1 gene are uncommon, but occur in ovarian, breast, esophageal, and pancreatic cancers (Chen et al. 1998; Goggins et al. 1998; Wang et al. 2000).

Epigenetic alterations may also account for alterations in receptor expression. Decreased expression of T $\beta$ RII or T $\beta$ RI has been reported in lung, gastric, and prostate cancer, among others. For example, in gastrointestinal tumors, the methylation status of the TGFBR1 promoter has been directly linked to its decreased expression. Hereditary mutations in the BMPR1A gene encoding the BMP type I receptor BMPRIA (ALK-3) cause juvenile polyposis, an autosomal dominant genetic disorder that predisposes patients to intestinal polyposis and cancer (Massagué et al. 2000; Derynck et al. 2001; Howe et al. 2001; Roberts and Wakefield 2003).

Analogously, genetic alterations that cause alterations in the expression of TGF- $\beta$ coreceptors can also blunt the pathway signaling activity. For example, inherited mutations in ENG gene encoding the betaglycan-related protein endoglin, a well-established BMP-9 coreceptor, cause hemorrhagic telangiectasia syndrome and are also associated with early onset of juvenile polyposis syndrome (Gallione et al. 2010). Additionally, overexpression of proteins that trap TGF- $\beta$ family members, including BMPs and activins, have also largely been associated with cancer progression and metastasis. Follistatin has been implicated in hepatocarcinogenesis (Rodgarkia-Dara et al. 2006), whereas Noggin and Gremlin have been reported to contribute to breast cancer bone and lung metastasis (Gao et al. 2012; Tarragona et al. 2012), as well as in skin basal carcinoma (Sneddon et al. 2006). Collectively, genetic inactivation of TGF- $\beta$ core components results in the elimination of most or all TGF- $\beta$ responses, including tumor-suppressor activities, and may result in outcomes that are very different from those due genetic alterations in effectors that only blunt part of the cytokine responses.

\section{Signaling Mediators}

Mutations in genes encoding R-Smads are rare in cancer and have been described in only a limited number of cases (Sjöblom et al. 2006). Specifically, mutations or loss of expression of SMAD3 are infrequent. Loss of SMAD3 expression has been reported in gastric cancer and T-cell lymphoblastic leukemia (Levy and Hill 2006), whereas loss of heterozygosity of the $18 \mathrm{q} 21$ chromosomal region containing SMAD2 and SMAD4/DPC4 (deleted in pancreatic carcinoma, locus 4 ) is observed in pancreatic and colon cancer (Massagué 2008).

Alterations of SMAD4/DPC4 are frequently observed in cancer and considered mostly a late event in tumor progression. In pancreatic tumors, chromosome 18q21 deletions, commonly affecting SMAD4, and systematic mutations or chromosomal aberrations that affect the other allele are common. The estimated frequencies of SMAD4 mutations in pancreatic cancers are within the range of mutations of other pancreatic oncogenes or tumor suppressors, such as KRAS, TP53, and CDKN2A (INK4) (Jaffee et al. 2002). In colorectal tumors without MSI, mutations in SMAD4 are also recurrent. Esophageal and other cancers also show mutations in SMAD4, with variable penetration rates (Barrett et al. 1996; Lei et al. 1996). Smad4 heterozygote inactivation in the context of the $A p c^{\Delta 716}$ mice, which serve a model for human familial adenomatous polyposis, promotes the development of polyps that are more malignant than those in $A p c^{\Delta 716}$ heterozygous alone. These show extensive stromal cell proliferation and submucosal invasion and support the notion that mutations in SMAD4 play a significant role in the malignant progression of colorectal tumors (Takaku et al. 1998). The critical role of SMAD4 inactivation in cancer progression was subsequently confirmed in pancreatic cancer (Bardeesy et al. 2006), despite the differential requirements of SMAD4 for each tissue in colon and pancreas development (Takaku et al. 1998; Bardeesy et al. 2006). Finally, germline 
mutations in SMAD4 have been described in a subset of juvenile patients with polyposis syndrome (Schwenter et al. 2012). This autosomal dominant inherited condition is characterized by the development of multiple hamartomatous tumors in the gastrointestinal tract and makes patients prone to cancer. Animal models provide insights into the physiological alterations and suggest a role for Smad 4 beyond the mucosa epithelium. Genetically engineered mice models in which Smad4 is specifically deleted in $\mathrm{T}$ cells or epithelia develop juvenile polyposis syndrome (Kim et al. 2006), suggesting that TGF- $\beta$ signaling in various cells types is a causal effector of genetic syndromes that predispose to cancer.

The disruption of the TGF- $\beta$ pathway can also occur at the level of mediators that repress the activity in response to antagonistic signals or feedback loops (Massagué 2008). Alterations that cause persistent high levels of Smad7 blunt TGF- $\beta$ signaling and have been described in endometrial carcinomas and thyroid follicular tumors (Cerutti et al. 2003; Dowdy et al. 2005). Similarly, increased Smad6 expression also attenuates TGF- $\beta$ family signaling, preventing its tumor-suppression function in pancreatic or breast cancer (Kleeff et al. 1999; de Boeck et al. 2016). As reported above for Smad4 depletion in genetic models, Smad7 overexpression in immune cells has been associated with chronic inflammation in the colonic mucosa. The expression of Smad7 variants is linked to predisposition to cancer, as shown by GWAS studies (Broderick et al. 2007), and to hepatic metastasis in colorectal cancer (Halder et al. 2008). Other mechanisms of direct inhibition of Smad activity have been described in pathology. c-Ski and SnoN are transcriptional corepressors of Smad transcriptional function. Deletions and amplifications of both SKI and SKIL, the gene encoding SnoN, have been detected in gastrointestinal tumors (Zhu et al. 2007). Finally, genomic translocations also perturb the pathway at the level of transcriptional complexes. In acute myelogenous leukemia (AML), proteins encoded by chimeric genes resulting from genomic translocations, including AML1/EVI-1 t(3:21) and AML1/ETO t(8:21), are known to bind to
Smad3 and suppress TGF- $\beta$ signaling at the transcriptional level (Letterio 2005).

Selective Failure of the TGF- $\beta$ Antitumor Response

Smad cofactors are among the key mediators of the pleiotropic TGF- $\beta$ response. These are transcription factors that bind Smad complexes and facilitate their binding to specific gene promoters. In the case of cytostatic gene responses, $\mathrm{p} 15^{\mathrm{INK} 4 \mathrm{~b}}$ and $\mathrm{p} 21^{\mathrm{CIP} 1}$, the transcription factors FoxO, C/EBP, and Miz-1 have been characterized as Smad cofactors. FoxO facilitates the binding of the Smad complex to the CDKN1A promoter, whereas C/EBP and Miz perform a similar role in the context of the $C D K N 2 B$ promoter. FoxO is, in turn, regulated by other signaling cascades, such as the PI3K-Akt pathway. A highly active PI3K-Akt pathway prevents FoxO nuclear localization, which, at the same time, impedes the formation of a nuclear FoxO-Smad complex. Hence, in tumors with a highly active PI3K-Akt pathway, the TGF- $\beta$ induced $\mathrm{p} 21^{\mathrm{CIP} 1}$ expression is impaired, thus blocking the TGF- $\beta$ cytostatic response (Seoane et al. 2004). In neuroepithelial cells, the corepressor FoxG1 binds FoxO, again impairing the induction of $\mathrm{p} 21^{\mathrm{CIP} 1}$ expression by TGF- $\beta$. FoxG1 is a transcription factor required for the development of the telencephalon in embryogenesis; however, it is highly expressed in glioblastoma, where it binds to the FoxO-Smad complex to recruit transcriptional corepressors such as Groucho, and prevent the induction of $\mathrm{p} 21^{\mathrm{CIP} 1}$ expression by TGF- $\beta$ (Seoane et al. 2004). Hence, in glioblastoma, the expression of high levels of FoxG1 impairs the p $21^{\mathrm{CIP} 1}$ response, thus precluding the antiproliferative effect to TGF- $\beta$.

On the other hand, the c-Myc binding factor Miz-1 binds to the transcription initiator region of the $C D K N 2 B$ and $C D K N 1 A$ promoters by forming a complex with $\mathrm{c}-\mathrm{Myc}$, which acts as transcriptional repressor. $\mathrm{p} 15^{\mathrm{INK} 4 \mathrm{~b}}$ expression is not induced by TGF- $\beta$ in tumors overexpressing Myc, because a repressive MycMiz-1 complex localizes close to the transcription initiation sites of the $C D K N 2 B$ and 
CDKN1A promoters, thus impairing the TGF- $\beta$ cytostatic program (Seoane et al. 2001, 2002).

Breast cancer cells from pleural fluids of patients with metastatic disease show normal TGF- $\beta$ receptor expression and Smad functions, even though their cytostatic response to TGF- $\beta$ is partially or completely lost. Half of the samples in this study lacked induction of $\mathrm{p} 15^{\mathrm{INK} 4 \mathrm{~b}}$ expression and repression of c-Myc expression in response to TGF- $\beta$, despite retaining other TGF- $\beta$ responses. This defect was found to be associated with overexpression of the dominant-negative $\mathrm{C} / \mathrm{EBP} \beta$ isoform LIP, which binds and inhibits the transcriptional active isoform LAP (Gomis et al. 2006b; Arnal-Estapé et al. 2010). Other studies establish an association between a high LIP:LAP ratio and tumor aggressiveness in breast cancer (Zahnow et al. 1997). Patient-derived metastatic breast cancer cells are also uniformly aberrant in the $I d 1$ response to TGF- $\beta$, which is induced instead of repressed (Padua et al. 2008). Id 1 expression is part of a lung metastasis gene expression signature associated with relapse in estrogen receptor-negative $\left(\mathrm{ER}^{-}\right)$breast cancer patients (Minn et al. 2005). In xenograft assays in mice using human breast cancer cell lines, Id 1 and Id 3 are essential for tumor reinitiation after the cells enter the lung parenchyma (Gupta et al. 2007). Therefore, the $I d 1$ response to TGF- $\beta$ in breast cancer switches from being tumor-suppressive to prometastatic.

Importantly, TGF- $\beta$ induces the expression of Id 1 in a specific population of glioblastoma cells that express high levels of CD44 and show cancer-initiating capabilities. Through the regulation of $I d 1$, TGF- $\beta$ induces the self-renewal of the $\mathrm{CD} 44^{\text {high }} / \mathrm{Id} 1^{+}$cancer-initiating cells, thereby promoting tumor relapse in glioblastoma (Anido et al. 2010).

\section{TGF- $\beta$ SIGNALING IN CANCER PROGRESSION: TUMOR GROWTH, CELL MIGRATION, AND INVASION}

Released from tumor-suppression constraints, cancer cells use the remaining TGF- $\beta$ responses with impunity to support tumorigenic features, including cancer progression, which encom- passes evasion of immune surveillance, tumor growth, migration, invasion, and metastasis.

Immune Evasion

TGF- $\beta$ stands out as a physiological immunosuppressor in humans (Gold 1999), and, accordingly, mice that systemically lack TGF- $\beta 1$ succumb to systemic inflammation and severe autoimmunity (Shull et al. 1992; Diebold et al. 1995). The effect of TGF- $\beta$ on the immune system is pleiotropic, affecting both the adaptive and innate immune system, including the regulation of T cells, natural killer (NK) cells, and macrophages (Fig. 4). The immunosuppressive response to TGF- $\beta$ allows tumors to evade the anticancer immune response, and, hence, TGF$\beta$ may be considered an appealing therapeutic target in the context of cancer immunomodulation (Li and Flavell 2008).

\section{T Cells}

TGF- $\beta$ inhibits both the proliferation and activation of $\mathrm{T}$ cells, thereby suppressing the differentiation and function of this cell population (Ranges et al. 1987; Park et al. 1997; Ahmadzadeh and Rosenberg 2005; Zhang et al. 2005b). TGF- $\beta$ has been shown to suppress pore-forming protein (PFP) expression in $\mathrm{CD}^{+}$cytotoxic $\mathrm{T}$ cells and to prevent T-cell cytolytic activity (Smyth et al. 1991). Interestingly, the regulation of PFP expression and the cytotoxic potential is independent of the proliferative response to TGF- $\beta$ (Smyth et al. 1991). In addition, TGF$\beta$ also inhibits the expression of granzyme $A$, granzyme B, perforin, Fas ligand, and interferon- $\gamma$, which together promote T-cell-mediated tumor cell cytotoxicity (Ahmadzadeh and Rosenberg 2005; Thomas and Massagué 2005). The expression of granzyme B and interferon$\gamma$ has been directly linked to Smad2 and/or Smad3 and ATF1 transcription factors downstream from the TGF- $\beta$ signal (Thomas and Massagué 2005). TGF- $\beta$ can inhibit $\mathrm{CD}^{+}{ }^{+} \mathrm{T}$ cell proliferation through its effect on macrophages (Alleva et al. 1995). Although TGF- $\beta$ is expressed in different cell populations, including the tumor cells (Rodón et al. 2014), and in 
J. Seoane and R.R. Gomis

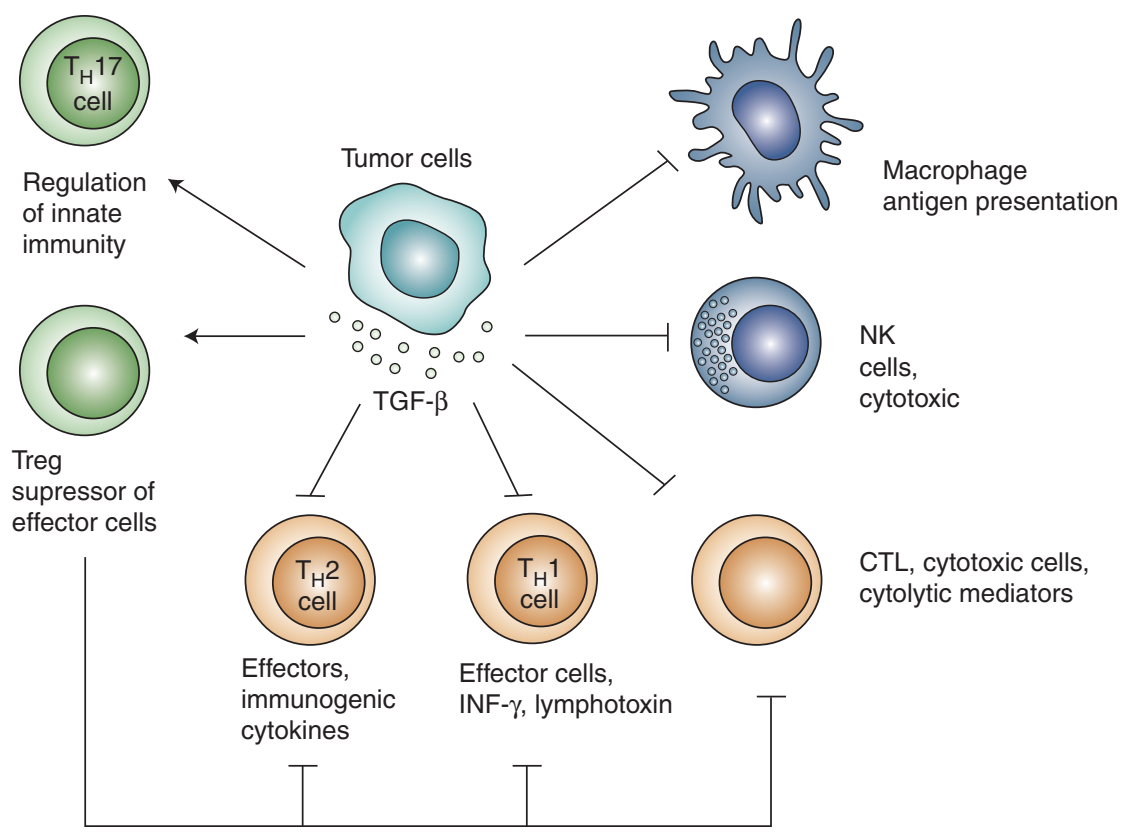

Figure 4. Pleiotropic effects of TGF- $\beta$ on the immune system. TGF- $\beta$ plays a role by controlling immune tolerance by the combined inhibition of most components of the innate (brown) and adaptive (blue) immune system directly or indirectly (green) through regulatory T cells. NK, Natural killer.

the tumor microenvironment (Chen et al. 2005b), regulatory T cells can secrete this cytokine, leading to the inhibition of $\mathrm{CD}^{+} \mathrm{T}$ cells (Chen et al. 2005b). In addition, TGF- $\beta$ can induce the differentiation of naïve $\mathrm{CD} 4^{+} \mathrm{T}$ cells into regulatory $\mathrm{T}$ cells in murine peripheral blood and pancreatic cancer (Chen et al. 2003; Moo-Young et al. 2009). Importantly, systemic inhibition of TGF- $\beta$ signaling has been shown to result in an antitumor response, in part mediated by the T-cell population (Kontani et al. 2006).

\section{NK Cells}

TGF- $\beta$ inhibits NK-cell effector functions and in this way contributes to a permissive microenvironment for tumor progression. The proliferation of MDA-MB-231 mammary carcinomas and their metastatic dissemination are strongly reduced in response to TGF- $\beta$ inhibition, and this effect is not observed in NK-celldeficient beige nude mice (Arteaga et al. 1993). Interestingly, TGF- $\beta$ regulates the effect of ta- moxifen treatment in vivo through the regulation of NK-cell populations (Arteaga et al. 1999). In this context, the tamoxifen-resistant human breast cancer cell line LCC2 responds to tamoxifen on TGF- $\beta$ neutralization. The antitumor effect of TGF- $\beta$ inhibition was initially associated with the activity of TGF- $\beta 2$ through the regulation of NK-cell-mediated cytotoxicity, because tumors grow irrespectively of TGF$\beta 2$ inhibition when cells are inoculated in mice that lack NK cells (Arteaga et al. 1999). This effect is attributed to the induction by TGF$\beta 2$ of a specific chemokine receptor repertoire, including the expression of CXCR4, and CXCR3, (Castriconi et al. 2013). Through these cytokines, TGF- $\beta$ attenuates the expression of the NKp30 as well as the NKG2D receptors, which are required for NK-cell-mediated tumor cell death (Castriconi et al. 2003). Interestingly, inhibition of NKG2D-mediated NK-cell cytotoxicity by TGF- $\beta$ enhances tumor growth and metastasis (Ghiringhelli et al. 2005; Smyth et al. 2006). Both NKG2D and NKp30 are recognition receptors that are triggered in response 
to cellular stress- that is, viral infection, genomic stress, and are able to trigger cytotoxicity (Kruse et al. 2014; Carapito and Bahram 2015). Accordingly, an inverse correlation has been identified between TGF- $\beta 1$ secretion and NKG2D expression in cancer patients (Lee et al. 2004), thereby indicating that the reduced NKG2D receptor expression may contribute to a decrease in NK-cell-associated tumor cell cytotoxicity (Lee et al. 2004). In addition, TGF- $\beta$ has been shown to suppress MHC class I and MHC class II expression in a number of cell populations (Geiser et al. 1993; Ma and Niederkorn 1995; Lee et al. 1997; Gorelik and Flavell 2001). Importantly, the TGF- $\beta$-induced repression of MHC class I expression in tumor cells results in decreased NK-cell-mediated tumor cell death (Ma and Niederkorn 1995). Overall, increased TGF- $\beta$ expression within the tumor microenvironment can lead to reduced NK-cell cytotoxic activity, thereby contributing to enhanced tumor progression and metastasis.

\section{Macrophages}

TGF- $\beta$ promotes monocyte recruitment and macrophage differentiation ( $\mathrm{Li}$ et al. 2006; Travis and Sheppard 2014). This cytokine has been shown to block both the priming of macrophages by interferon- $\gamma$ and their activation by lipopolysaccharide, thus preventing these phagocytic cells from inducing tumor cell death (Haak-Frendscho et al. 1990). Many of the functional responses to TGF- $\beta$ can be attributed to the regulation of gene expression in monocytes and macrophages. In monocytes, TGF- $\beta$ promotes the expression of proinflammatory mediators, including interleukin-1 (IL-1) and interleukin-6 (IL-6), while suppressing oxygen-free radical production (Fontana et al. 1992). In macrophages, TGF- $\beta$ suppresses the expression of chemokines including macrophage inflammatory protein $1 \alpha$ and 2 (MIP$1 \alpha$, MIP-2) and the chemokine CXCL1 factor, the cytokine granulocyte-macrophage colonystimulating factor (GM-CSF) and interleukins IL-1 $\beta$, IL-8, and IL-10 (McDonald et al. 1999), which in macrophages cause the acquisition of a deactivation state that prevents early, premature immune activation (Varol et al. 2015). Interestingly, targeted inactivation of Eng in cells of myeloid lineage, resulting in the absence of the TGF- $\beta$ coreceptor endoglin, which controls monocyte-macrophage differentiation, results in phagocytic impairment and thus represses the contribution of macrophages to the initiation of the immune response (Ojeda-Fernández et al. 2016). TGF- $\beta$ can also enhance the response to chemotactic signals that are known to be abundant within the tumor pro-inflammatory microenvironment, such as the stromalcell-derived factor SDF-1/CXCL12 that acts through the CXCR4 receptor (Wang et al 2001). In this regard, stimulation of monocytes and macrophages with the cytokine SDF-1 increases the expression of CXCR4 (Wang et al. 2001), leading to tumor progression (Orimo et al. 2005). Together, these results suggest that TGF- $\beta$ regulates the recruitment, differentiation, activation, gene expression profile and response to external stimuli of macrophages, thereby directly affecting tumor progression.

\section{Autocrine Mitogens}

By disabling the cytostatic program of TGF- $\beta$, tumor cells turn TGF- $\beta$ signaling to their advantage to promote cell proliferation, by stimulating the production of autocrine mitogenic factors. In advanced cancer, including glioblastoma, the TGF- $\beta$ pathway acts as an oncogenic factor. On loss of the tumor-suppressor activity, including loss of induction of $\mathrm{p} 15^{\text {INK4b }}$ expression and/or inactivation of $\mathrm{Rb}$, some tumors show aberrantly high TGF- $\beta$ signaling. This activity can be sustained by an autocrine loop, whereby TGF- $\beta$ induces the expression TGF$\beta 2$, leading to high levels of TGF- $\beta 2$. Mechanistically, cAMP-responsive element binding protein 1 (CREB1) binds to the TGFB2 promoter, and cooperates with Smad 3 in TGF- $\beta$-induced activation of TGFB2 transcription. The PI3KAkt and ribosomal S6 kinase (RSK) pathways induce the phosphorylation of CREB1 that then binds the TGFB2 promoter in complex with Smad3, generating the TGF- $\beta 2$ autocrine loop in glioblastoma cells (Rodón et al. 2014). In certain cases, the hyperactivation of the 
TGF- $\beta$ pathway is not achieved by increased ligand expression but by stabilization of the TGF- $\beta$ receptor complex. For example, the gene encoding the deubiquitylating enzyme USP15 that targets the T $\beta R I$ receptor is amplified in some cancers, and this promotes the stabilization of the T $\beta R I$ receptor, thus inducing increased activation of the TGF- $\beta$ pathway (Eichhorn et al. 2012). Glioblastoma cells also produce platelet-derived growth factor B (PDGF-B) in response to TGF- $\beta$ (Jennings and Pietenpol 1998) in a process that depends on the methylation state of the PDGFB gene (Bruna et al. 2007). Hypomethylation of the $P D G F B$ promoter occurs in patients with high TGF- $\beta$ expression and activated Smads and correlates with poor prognosis. Thus, the epigenetic state of the PDGFB gene contributes to the tumor cell fate in response to TGF- $\beta$.

\section{Microenvironment as a Source} of Mitogenic Signals

The loss of TGF- $\beta$-induced cytostasis in tumor cells allows the tumor to profoundly alter the host immune response to TGF- $\beta$. In parallel, the tumor cell can also adapt its environment to favor tumor initiation and progression. In this case, the process relies on the plasticity of both the tumor cells and stromal cells (Fig. 5). This process may be central in metastasis, as cross talk between disseminated tumor cells and distant organ microenvironments may establish tissue-specific dependence. The tumor microenvironment is comprised of various types of nonepithelial cell types, including fibroblasts, endothelial and immune cells, and extracellular matrix proteins (Fig. 5). The activation status of TGF- $\beta$ signaling during tumor progression depends on whether the epithelial cells retain a functional TGF- $\beta$ signaling pathway in full or in part, as described above (Massagué and Gomis 2006). However, in certain tumor types, such as colorectal and prostate cancers, elevated levels of TGF- $\beta$ correlate with poor prognosis (Tsushima et al. 1996; Wikstrom et al. 1998) and relapse (Walker and Dearing 1992; Friedman et al. 1995; Calon et al. 2012), and are associated with increased TGF- $\beta$ signaling in tumor-adjacent cells and not in the malignant epithelial tissue.

The mobilization of mesenchymal precursors and generation of myofibroblasts on TGF$\beta$ stimulation, as well as the recruitment of fibroblasts, are components of the protumorigenic and invasive contribution of the cytokine (De Wever and Mareel 2003). The myofibroblasts are highly motile, retain features of fibroblasts and smooth muscle cells, and facilitate tumor development as cancer-associated fibroblasts (De Wever and Mareel 2003; Allinen et al. 2004). These cells produce a range of proteases, cytokines (e.g., TGF- $\beta$, VEGF, EGF, PDGF, FGF, IGF-1, and type I collagen), and chemokines (e.g., CXCL12) that support cancer invasion, proliferation and angiogenesis. For example, in culture, these cells guide the invasion of colon cancer cells through a collagen matrix, in a process that depends on TGF- $\beta$. These and other observations support the notion that TGF- $\beta$ signaling makes an important contribution to stroma- and cancer-associated fibroblasts (Hawinkels et al. 2009; Calon et al. 2012).

Fibroblasts in the tumor microenvironment differ from their normal counterparts, as can be seen by the expression of $\alpha$-smooth muscle actin ( $\alpha$-SMA), fibroblast surface protein (FSP1, also known as S100A4), and fibroblast-activated protein (FAP) (Bauer et al. 2010; Navab et al. 2011). Interestingly, fibroblast-like cells both produce and respond to TGF- $\beta$, triggering a set of responses that support tumor development and progression. By means of genetic deletion, it has been shown that CLIC4 (chloride intracellular channel 4) is required for TGF- $\beta$ induced expression of $\alpha$-SMA and extracellular matrix proteins in fibroblasts (Shukla et al. 2014). In addition, TGF- $\beta$ triggers an autocrine signaling loop that sustains myofibroblast differentiation (Kojima et al. 2010). In addition to the recruited fibroblasts, cancer-associated fibroblasts were also shown to be derived from other cell types. Among these, TGF- $\beta$-induced transdifferentiation of endothelial cells into mesenchymal cells has been proposed to lead to expression of the fibroblast marker FSP1 and repression of expression of the endothelial marker CD31 (Zeisberg et al. 2007a). Addition- 
TGF- $\beta$ Signaling and Cancer

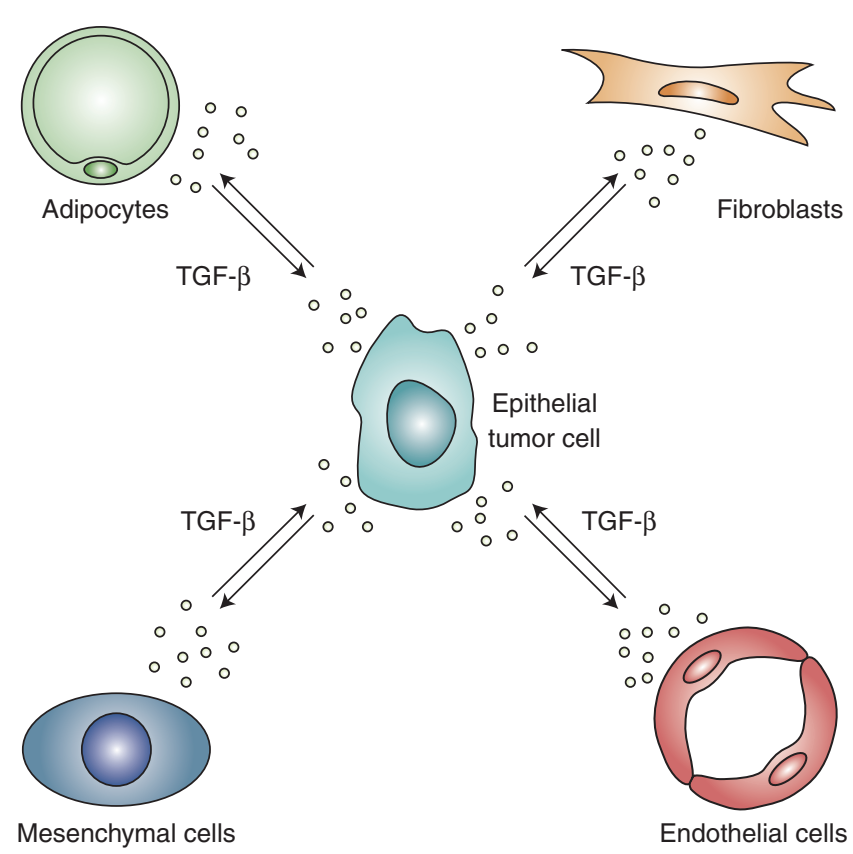

Figure 5. TGF- $\beta$ signaling in cells adjacent to carcinoma cells and not in the malignant carcinoma cells. TGF- $\beta$ is produced and activates signals in various cell types in the tumor environment. These include tumor epithelial cells, fibroblasts, endothelial cells, mesenchymal cells, and adipocytes.

ally, TGF- $\beta$-induced EMT was proposed to be a potential source of tumor fibroblasts (Oft et al. 2002; Petersen et al. 2003). Collectively, these lines of evidence point to a central role of TGF- $\beta$ in the tumor microenvironment, where it supports the coevolution of the stroma, with epithelial transformation and progression toward malignancy.

Direct cell-cell and paracrine mechanisms mediate TGF- $\beta$ cross talk between tumor epithelial cells and tumor-associated fibroblasts. In prostate cancer, tumor and stromal cells coevolve, and paracrine cytokines expressed by prostate fibroblasts, on loss of TGF- $\beta$ responsiveness, further support tumor cell growth and dissemination (Bhowmick et al. 2004; Bhowmick and Moses 2005; Li et al. 2012). Similarly, breast cancers, melanomas, and gliomas that largely retain a functional TGF- $\beta$ pathway and specifically escape the cytokine cytostatic effect, use TGF- $\beta$ signaling to express prometastatic factors that then support growth at distant sites. These factors include JAGGED1, angiopoietin-like 4 (ANGPTL4), IL-11, and others described that are in the last section of this review.

A significant proportion of colon and pancreatic tumors have lost the TGF- $\beta$-induced cytostatic response as a result of alterations at the level of the receptors that inactivate the pathway (Markowitz et al. 1995). In colon cancer, tumor cells produce and release TGF- $\beta$ in the microenvironment, thereby unveiling a prometastatic program that is associated with risk of relapse. This risk results from TGF- $\beta$ activity on stromal cells, including fibroblasts, which increases the efficiency of dissemination, whereas treatment with T $\beta$ RI inhibitors prevents metastasis (Calon et al. 2012, 2015). Central to the TGF- $\beta$ stromal response is the secretion of IL-11 by cancer-associated fibroblasts, a process that triggers JAKSTAT3 signaling and confers a survival advantage to disseminated tumor cells (Calon et al. 2012, 2015). The TGF- $\beta$ effects in the microenvironment are also observed in a mouse model of aggressive breast cancer metastasis, whereby cancer stem cells that are disseminated to the lungs misuse TGF- $\beta$ signaling in the stroma to 
create a niche that allows for metastasis (Malanchi et al. 2012). Interestingly, the TGF- $\beta$ signaling-dependent education of the host stroma of the target organ by tumor cells is bimodal, whereby TGF- $\beta$ signaling initially promotes EMT and niche activation, and the newly activated niche fibroblasts then promote a transition of the carcinoma cells toward a more epithelial phenotype to enable metastatic colonization (Del Pozo Martin et al. 2015). Similarly, low radiation triggers the education of the metastatic niche, dependent on TGF- $\beta$ signaling (Biswas et al. 2007; Nguyen et al. 2011). These lines of evidence suggest that the dependence of the primary microenvironment on TGF- $\beta$ could be exploited to improve the treatment of cancer.

Although there is clear agreement on the contribution of TGF- $\beta$ to the tumor microenvironment, experiments using xenografts and genetically engineered mouse models report contra-intuitive effects of TGF- $\beta$ signaling in fibroblasts. Strong evidence supports a role for TGF- $\beta$ signaling in fibroblasts promoting tumor growth in breast, nonsmall cell lung and colorectal cancer (Kuperwasser et al. 2004; Navab et al. 2011; Nguyen et al. 2011; Calon et al. 2012, 2015; Malanchi et al. 2012). However, conditional inactivation of Tgfbr2 in mouse fibroblasts has been shown to support prostate and forestomach tumorigenesis by impinging on HGF signaling through c-Met and Ron (Bhowmick et al. 2004; Cheng et al. 2008; Li et al. 2012). Indeed, in that scenario loss of TGF- $\beta$ signaling in stromal fibroblasts may result in HGF-mediated cell cycle regulation in the tumor cells, by suppressing the expression of the CDK inhibitors, $\mathrm{p} 27^{\mathrm{Kip} 1}$ and $\mathrm{p} 21^{\mathrm{CIP} 1}$, and activating the expression of c-Myc (Bhowmick et al. 2004).

Beyond direct effects of TGF- $\beta$ on the stroma and tumor cells, mechanisms that lead to an increase in active TGF- $\beta$ level may also contribute to this process. TGF- $\beta$ is secreted in complex with latent TGF- $\beta$ binding protein (LTBP), which controls the latency of the cytokine. This represents another level of regulation, as mice deficient in LTBP-TGF- $\beta$ association display increased inflammation and tumorigenesis (Shibahara et al. 2013). In addition, TGF- $\beta$ signaling in fibroblasts is enhanced when these cells are combined with cancer cell-conditioned media. This observation points to a synergistic or additive effect of TGF- $\beta$ with other secreted factors (Hawinkels et al. 2009). Increased expression of matrix metalloproteinase 9 and mechanical stress have been reported to enhance breast cancer malignancy as a result of increased TGF- $\beta$ activation (Stuelten et al. 2005; Wipff et al. 2007). Similarly, senescence-associated metabolic changes may further stimulate these synergistic or additive effects (Capparelli et al. $2012 a, b, c)$. Finally, these effects may also be promoted by the transcriptional and translational networks occurring as a result of the TGF- $\beta$ induced EMT of cancer cells (Moustakas and Heldin 2014).

TGF- $\beta$ signaling also triggers tumor angiogenesis. Cooperative actions with other signaling cascades in an autocrine/paracrine manner, including vascular endothelial growth factor (VEGF), basic fibroblast growth factor (bFGF), PDGF, Notch, connective tissue growth factor (CTGF), and angiopoietin, stimulate angiogenesis by promoting endothelial cell migration and proliferation (ten Dijke and Arthur 2007; Sakurai and Kudo 2011; Neuzillet et al. 2014). Interestingly, depending on the TGF- $\beta$ signaling levels and the TGF- $\beta$ receptor status, a context-dependent angiogenic or antiangiogenic effect is observed. These threshold-dependent effects highlight the complex and intricate circuitry that defines how a given cell reads TGF- $\beta$ signaling. Low levels of TGF- $\beta$ signaling contribute to angiogenesis indirectly by inducing the expression of proangiogenic factors (VEGF, bFGF, CTGF) and other activities such as proteases, whereas high levels of signaling through Smad2 and Smad3 stimulate basement membrane formation, recruit smooth muscle cells, and inhibit endothelial cell growth (Sakurai and Kudo 2011). These effects are recapitulated in hepatocellular carcinoma and gliomas (Ito et al. 1995; Zhang et al. 2011).

\section{TGF- $\beta$ INDUCES EMT IN CANCER PROGRESSION}

The role of TGF- $\beta$ in promoting tumor progression and fibrosis has long been associated with 
its capacity to produce an EMT through activation of E-cadherin repressors and EMT inducers (Acloque et al. 2009). EMT is crucial for normal development and is a pathological feature of cancer invasion (Thiery 2003; Lamouille et al. 2014). Cells undergoing EMT are characterized by a decrease or loss of E-cadherin expression and epithelial cell junctions, and an architectural rearrangement of the cytoskeleton into a mesenchymal pattern, resulting in cell motility and invasive properties. EMT is pivotal in various embryonic processes, such as gastrulation and formation of neural crest and structures of the heart. This process is driven by a set of transcription factors belonging to the zincfinger, bHLH, and forkhead families, including Snail (Snail1), Slug (Snail2), Twist, and the zinc finger E-box binding homeobox proteins ZEB1 (also known as $\delta E F 1$ ) and ZEB2 (also known as SIP1). By inducing EMT, TGF- $\beta$ allows cancer cells to acquire the capacity to invade and disseminate.

In cancer, TGF- $\beta$-induced EMT occurs in transformed epithelial cells that are capable of propagating a tumor (Mani et al. 2008). In this context, the EMT program supports tumor invasion and dissemination by releasing tumor cells into the surrounding environment and promoting their motility. Tumor cells with EMT features have been shown to lead the cancer invasion fronts, and therefore these cells are probably the first to leave the primary tumor to then colonize distant sites and disseminate the disease (Friedl et al. 2012). Collectively, EMT confers invasiveness, motility, and progenitor-like features that are required for metastatic spread to this cell population. In addition, EMT also contributes to chemoresistance in breast and pancreatic cancer (Zheng et al. 2015). These features of EMT occur in a concerted manner under some circumstances; however, they are not always observed concomitantly, and individually do not imply cellular engagement in EMT. Although EMT is important for tumor dissemination, malignant cells commonly revert to an epithelial phenotype through a mesenchymal-to-epithelial transition (MET) that is required to colonize distant sites and form metastases (Polyak and Weinberg
2009; Ocana et al. 2012). Therefore, it is tempting to speculate that reduced exposure to or modulation of TGF- $\beta$ signaling on dissemination contributes to such a phenotypic reversion. Consistent with this notion, TGF- $\beta$-induced expression of Id 1 promotes metastatic colonization in breast cancer cells (Gupta et al. 2007) and represses Twist expression in basal breast cancer cells that infiltrate the lung parenchyma (Stankic et al. 2013). Although one may speculate that local high concentrations of the TGF$\beta$ may define TGF- $\beta$-mediated EMT before cell dissemination from the primary tumor, it is unknown why, when, or where MET is engaged and the extent to which TGF- $\beta$ contributes to this process.

TGF- $\beta$ was initially shown to induce an EMT in mammary cell lines and in mouse models of skin carcinogenesis (Miettinen et al. 1994; Portella et al. 1998; Thiery 2003; Derynck and Akhurst 2007). Mechanistically, the concerted action of TGF- $\beta$ signaling, oncogenic Ras, and mutant p53 leads to p63 sequestration, causing inactivation of the tumor-suppressive function of the growth factor (Adorno et al. 2009). Under these circumstances, TGF- $\beta$ and Ras cooperate to induce Snaill expression and EMT in epithelial cells (Oft et al. 1996; Peinado et al. 2003; Derynck and Akhurst 2007). Accordingly, forced expression of Snaill confers resistance to TGF- $\beta$-induced apoptosis and is sufficient to promote EMT in adult hepatocytes. In contrast, Snaill depletion restores the cell death response (Franco et al. 2010). In mammary epithelial cells with increased Ras expression, TGF- $\beta$-induced EMT depends on NF-кB (Huber et al. 2004). In contrast, poly(ADP-ribose) polymerase-1 (PARP-1) dissociates Smad complexes from DNA, thereby attenuating TGF- $\beta$ signaling and EMT (Lönn et al. 2010). In other contexts, Smad-mediated complexes may indirectly control the expression of SNAIL1, SNAIL2, and TWIST through high mobility group A2 (HMGA2) (Thuault et al. 2006). Additionally, T $\beta$ RII-mediated phosphorylation of Par6 may also result in the resolution of cell junctions, thereby contributing to cell migration and invasion (Ozdamar et al. 2005). Generally, TGF- $\beta$ induced EMT is considered a protumorigenic 
event. However, in TGF- $\beta$-sensitive pancreatic ductal adenocarcinoma (PDA) cells EMT becomes lethal by converting TGF- $\beta$-induced Sox 4 from an enforcer of oncogenesis to a proapoptotic trigger (David et al. 2016). In these cells, Smad4 is necessary for EMT but not for Sox 4 induction by TGF- $\beta$. Thus, the Smad 4 inactivation status defines whether TGF- $\beta$ can be protumorigenic or tumor-suppressive (David et al. 2016). Collectively, these results highlight a strong interdependence between TGF- $\beta$ and EMT induction, and illustrate that the cellular outcome is subject to cell-type- and contextspecific determinants.

In human cancers, the TGF- $\beta$-induced EMT gene program is encompassed within the gene expression profile of $\mathrm{CD} 44^{+} / \mathrm{CD} 24^{\text {low }}$ breast cancer cell population, which are seen as the tumor-initiating cells (Shipitsin et al. 2007), suggesting that activation of TGF- $\beta$ signaling leads to EMT. Blockade of T $\beta$ RI signaling, using specific kinase inhibitors, causes reexpression of epithelial-like characteristics. This implies that the $\mathrm{CD} 44^{+} / \mathrm{CD} 24^{\text {low }}$ tumor-propagating cell population may have undergone EMT, and that this process is, in part, mediated by TGF- $\beta$. The existence of tumor-initiating cells or socalled cancer stem cells (CSCs) is built on the concept of cellular plasticity, which is in agreement with the finding that TGF- $\beta$-induced EMT confers stem-cell-like properties (Mani et al. 2008), thereby linking the two concepts.

TGF- $\beta$ also supports the generation of fibroblasts from epithelial cells through EMT, and from endothelial cells through a closely related process named endothelial-to-mesenchymal transition (EndMT). Adult fibroblasts are traditionally thought to propagate by proliferation (Weber 1997) or to differentiate from embryonic mesenchymal cells (Maric et al. 1997; Lang and Fekete 2001). However, during kidney, lung, liver, and tumors fibrosis, bone marrowderived, endothelial, and epithelial cells contribute to fibroblast accumulation (Iwano et al. 2002; ten Dijke and Arthur 2007). As described above, TGF- $\beta$, in combination with other stimuli such as EGF and FGF-2 (bFGF), promotes EMT. Concomitant activation of Ras, Src, and other pathways facilitates important transcrip- tional regulation that leads to loss of adhesion and induction of the EMT. This process produces new fibroblasts in a model of experimental renal fibrosis under pathologic stress (Iwano et al. 2002).

EndMT plays a normal role in embryonic development of the heart, and has pathological roles in pulmonary fibrosis and in response to hypertension. The endocardium produces a mesenchymal cell population in the atrioventricular cushion, the primordia of the valves and the septa of the adult heart through EndMT (Eisenberg and Markwald 1995). This process occurs in a spatiotemporally restricted manner in the outflow tract and atrioventicular canal. It is triggered by TGF- $\beta$ and BMP signals from the myocardium (Camenisch et al. 2002; Liebner et al. 2004), and leads to cardiac fibrosis and fibroelastosis when deregulated (Zeisberg et al. 2007b; Zeisberg and Kalluri 2015). In this context, TGF- $\beta 1$ promotes cardiac fibrosis by inducing EndMT in adult coronary endothelial cells, whereas BMP-7 reverses this effect. In the lung, EndMT occurs in bleomycin-induced fibrosis (Hashimoto et al. 2010; Choi et al. 2016), thus providing a source of myofibroblasts. Similarly, EndMT is pivotal in the accumulation of mesenchymal-like cells in obstructive pulmonary vascular lesions that cause pulmonary hypertension (Ranchoux et al. 2015). Both processes are TGF- $\beta$-dependent and inhibited by the endothelial heat shock protein 1 (HSPB1) (Choi et al. 2016). Furthermore, EndMT relies on the EMT transcription factor Snail (van Meeteren and ten Dijke 2012). Outside the context of fibrosis, EndMT is an important source of cancer-associated fibroblasts in the Rip-Tag2 mouse model of pancreatic carcinoma, and myofibroblast accumulation has been established in solid tumors (Zeisberg et al. 2007a; Erez et al. 2010).

\section{Tumor-Initiating Properties}

Cancer cells endowed with tumor-initiating capacities, or CSCs, account for the generation of tumors at the primary site, as well as on dissemination (Oskarsson et al. 2014). Their properties are particularly significant in metastatic 
cancer dissemination, when cells are subjected to highly adverse conditions and only few cells eventually succeed in generating secondary tumors. Cancer progression involves cell proliferation, invasion, migration, dissemination through circulation, extravasation and survival on arrival at distant sites, and eventual colonization. However, when cells do not have tumorinitiating properties, metastatic dissemination may not cause clinical symptoms. CSC properties may already be present in the primary tumor. Cell heterogeneity is characteristic of many cancers, as a result of hierarchical organization or exposure to environmental cues, and cancer cells expressing such markers are present in patients and capable of generating metastases when inoculated into immunodeficient mice (Pece et al. 2010; Merlos-Suárez et al. 2011; Baccelli et al. 2013).

TGF- $\beta$ enhances the CSC potential in glioblastoma (Anido et al. 2010) and collaborates with canonical and noncanonical Wnt signaling to induce activation of mesenchymal CSC traits in association with an EMT program (Scheel et al. 2011). TGF- $\beta$ sustains a CD $44^{\text {high }} / \mathrm{Id} 11^{\text {high }}$ glioma-initiating cellular population responsible for tumor initiation, relapse, and therapeutic resistance (Anido et al. 2010). In addition, TGF- $\beta$ also supports self-renewal of glioma-initiating cells through the induction of Sox 2 expression (Ikushima et al. 2009) or the expression of leukemia inhibitory factor (LIF) (Peñuelas et al. 2009). LIF is a cytokine with a crucial role in embryonic stem cells. It is highly secreted by cells in certain glioblastomas, promotes selfrenewal of cancer-initiating cells and facilitates tumor relapse (Peñuelas et al. 2009). This cell population tends to be localized at the perivascular niche and edges of tumors, and confers poor prognosis in glioblastoma patients. TGF$\beta$ has also been shown to induce the CSC marker CD133 in hepatic epithelial cells that behave aggressively when grafted in mice (You et al. 2010) and gain resistance to chemotherapy and TGF- $\beta$-mediated apoptosis (Ding et al. 2009). A critical role for TGF- $\beta$ in maintaining leukemia-initiating cells has also been proposed in chronic myeloid leukemia (CML). In these cells, TGF- $\beta$ induces Akt activation, and con- trols FoxO3a localization and inactivation, and its inhibition concomitantly with that of a BCRABL causes an efficient depletion of CML in vivo (Naka et al. 2010). In-depth studies suggest that the TGF- $\beta$-FoxO-BCL6 axis interacts with nutrient signaling to maintain CML stem cells. This signal integration relies on FoxO3Smad3 association and is controlled by p38 MAPK activity (Naka et al. 2015). Overall, the evidence that TGF- $\beta$ promotes the generation and maintenance of CSC features is compelling.

As described already, TGF- $\beta$-induced EMT and tumor-initiating properties occur concomitantly at times (Valastyan and Weinberg 2011), and both the EMT and stem-cell-like markers are coexpressed in circulating tumor cells from patients with metastasis (Aktas et al. 2009; Baccelli et al. 2013; Yu et al. 2013). Although TGF- $\beta$ induces EMT, and thus promotes loss of adhesion and polarity of malignant cells at the invasive front and acquisition of migration properties (Oft et al. 1996; Xu et al. 2009), enforced expression of EMT transcription factors, such as Twist in breast cancer cells provides stem-cell assets (Mani et al. 2008; Wellner et al. 2009; Scheel et al. 2011). In addition to the role of TGF- $\beta$ signaling in EMT and, hence, in stemcell-like properties, other TGF- $\beta$ family members play key roles in cancer progression and metastasis by suppressing self-renewal and promoting cancer cell differentiation. BMP signaling in the lung parenchyma or bone cavity was shown to impose latency in breast cancer cells by restraining CSC properties and supporting the differentiation of malignant cells, as well as by modulating the metastatic site at the bone. Coco or related BMP-sequestering antagonists support lung metastatic progression (Gao et al. 2012), whereas Noggin reinforces bone colonization by breast cancer cells in a cell-autonomous and nonautonomous manner (Tarragona et al. 2012).

\section{TGF- $\beta$ in Metastasis}

The function of TGF- $\beta$ in cancer progression extends beyond the primary site and has also been implicated in facilitating distant metastasis. The expression of TGF- $\beta 1$ in infiltrating 
breast carcinomas has long been associated with metastatic outcomes (Dalal et al. 1993), whereas low expression of TGF- $\beta$ receptors in ER-negative breast cancers has been linked to favorable prognosis (Buck et al. 2004). In addition, blockade of TGF- $\beta$ signaling in mice with mammary tumors that were subjected to radiation or chemotherapy has been shown to prevent lung metastasis (Biswas et al. 2007). Taken together, the results of many different studies implicate TGF- $\beta$ signaling in metastatic dissemination. However, contradictory observations have been reported in mouse models. Whereas the expression of activated TGF- $\beta 1$ in $\mathrm{ErbB} 2 / \mathrm{Neu}$ mouse mammary tumors enhances metastasis (Muraoka et al. 2003), expression of a dominant-negative T $\beta$ RII unexpectedly also promotes metastasis in the same model (Novitskiy et al. 2014). TßRII depletion by targeted gene inactivation or dominant-negative interference increases metastasis in polyoma middle-T antigen (PyMT)-tumors (Forrester et al. 2005), and inhibits metastasis of prostate cancer xenografted in mouse (Zhang et al. 2005a). Thus, contextual cues based on tumor type or event within tumor subtypes appear to have a pivotal effect on the potential of TGF- $\beta$ signaling to trigger a metastatic outcome.

In ER-negative breast cancer, TGF- $\beta$ signaling has been associated with lung metastasis (Padua et al. 2008). Transient exposure of breast cancer cells to TGF- $\beta$ promotes their extravasation from blood vessels and entry into the lung by activating the expression of the adipokine ANGPTL4 (Padua et al. 2008). That study revealed that the later stages of metastasis are influenced by transient signals produced in the primary tumor microenvironment. Similarly, TGF- $\beta$ - and Smad-dependent induction of PTHLH, which encodes parathyroid hormonelike protein (also known as PTHrP), CTGF, and $J A G G E D 1$ may enhance osteolytic metastasis of breast, prostate and melanoma cancer cells (Kang et al. 2003b; Mohammad et al. 2011; Sethi et al. 2011; Xu et al. 2015) and has been confirmed in malignant cells derived from metastatic breast cancer (Gomis et al. 2006b). In prostate cancer, TGF- $\beta$ also significantly upregulates PMEPA1 expression. PEMPA1 inter- acts with R-Smads and ubiquitin ligases, blocking TGF- $\beta$ signaling independently of the proteasome (Fournier et al. 2015). Blockade of this negative feedback loop by methylation of the PMEPA1 promoter increases the prometastatic features of prostate cancer (Fournier et al. 2015). The development and outgrowth of bone metastatic lesions relies on a cellular and molecular network of interactions between cancer and stromal cells of the bone microenvironment, a process in which TGF- $\beta$ plays a pivotal role. Malignant breast cells have the capacity to alter the balance between the two main bone-preserving cell populations, namely, osteoblasts and osteoclasts, leading to bone destruction and metastatic growth. PTHrP produced by tumor cells promotes osteoclast differentiation, resulting in bone destruction, which in turn leads to increased availability of growth factors, including TGF- $\beta$, which are stored in bone matrix, thus further stimulating the malignancy of the transformed cells in what is named a "vicious cycle" (Guise et al. 1996; Mundy 2002). TGF- $\beta$ released on osteoclast degradation of the bone causes a signal in tumor cells, thus triggering Smad-dependent Jagged 1 expression, which in turn further supports the osteoblast differentiation induced by Notch (Sethi et al. 2011). Concomitantly, pathological TGF- $\beta$ release from the bone causes muscle weakness by decreasing $\mathrm{Ca}^{2+}$-induced muscle force. TGF- $\beta$ induced Smad signaling drives the expression of NADPH oxidase 4 (Nox4) in the muscle, which in turn increases ROS production and intracellular $\mathrm{Ca}^{2+}$ depletion (Waning et al. 2015). Overall, the contribution of TGF- $\beta$ signaling to metastasis is incompletely understood, and appears to cover a broad spectrum of tumor types and pathological consequences. Further research efforts are needed to gain a more comprehensive perspective.

\section{CONCLUSIONS AND THERAPEUTIC IMPLICATIONS}

From the study of the pathways that govern tumorigenesis and cancer progression, numerous novel putative therapeutic targets have emerged, among them the TGF- $\beta$ pathway. Sev- 
eral small and large molecule compounds have been developed with the aim to inhibit TGF- $\beta$ signaling. However, TGF- $\beta$ exerts dual and opposing roles in oncogenesis. Therefore, a detailed understanding of the TGF- $\beta$ biology in cancer is required to design successful therapeutic approaches and prevent unwanted side effects. The dual effect of TGF- $\beta$ on cancer is explained by the pleiotropic nature of TGF- $\beta$. Gene responses to TGF- $\beta$ are determined by the cellular context and the integration of the TGF$\beta$ pathway with other signals received by the cell. Such an understanding of the cellular context that determines the switch of the TGF- $\beta$ pathway toward a tumor-promoting factor is essential to predict in which patients TGF- $\beta$ signaling might be a suitable therapeutic target. Little by little, we are acquiring greater knowledge of the TGF- $\beta$ pathway. This knowledge will ultimately allow the rational design of several clinical trials to test anti-TGF- $\beta$ compounds. However, to fully evaluate the complex and pleiotropic TGF- $\beta$ pathway as a valid therapeutic target against cancer, further research is required to unravel the molecular mechanisms involved in the loss of the tumor-suppression response and gain of the oncogenic response to this cytokine.

\section{ACKNOWLEDGMENTS}

We thank J. Urosevic and V. Chiganças for helpful discussions and I. Joval for assistance in mounting the figures. J.S. and R.R.G. are supported by the Institució Catalana de Recerca i Estudis Avançats. Their research is supported by Grants from the Generalitat de Catalunya (2014 SGR 535) and the Spanish Ministerio de Ciencia e Innovación (MICINN) (SAF2013-46196, FEDER funds) to R.R.G., and from the Asociación Española contra el Cáncer (AECC), the Josef Steiner Foundation, and FIS PI13/ 02661 to J.S.

\section{REFERENCES}

Acloque H, Adams MS, Fishwick K, Bronner-Fraser M, Nieto MA. 2009. Epithelial-mesenchymal transitions: The importance of changing cell state in development and disease. J Clin Invest 119: 1438-1449.
Adorno M, Cordenonsi M, Montagner M, Dupont S, Wong C, Hann B, Solari A, Bobisse S, Rondina MB, Guzzardo V, et al. 2009. A mutant-p53/Smad complex opposes p63 to empower TGF $\beta$-induced metastasis. Cell 137: 87-98.

Ahmadzadeh M, Rosenberg SA. 2005. TGF- $\beta 1$ attenuates the acquisition and expression of effector function by tumor antigen-specific human memory CD8 T cells. J Immunol 174: 5215-5223.

Aktas B, Tewes M, Fehm T, Hauch S, Kimmig R, KasimirBauer S. 2009. Stem cell and epithelial-mesenchyma transition markers are frequently overexpressed in circulating tumor cells of metastatic breast cancer patients. Breast Cancer Res 11: R46.

Alarcón C, Zaromytidou AI, Xi Q, Gao S, Yu J, Fujisawa S, Barlas A, Miller AN, Manova-Todorova K, Macias MJ, et al. 2009. Nuclear CDKs drive Smad transcriptional activation and turnover in BMP and TGF- $\beta$ pathways. Cell 139: 757-769.

Alleva DG, Walker TM, Elgert KD. 1995. Induction of macrophage suppressor activity by fibrosarcoma-derived transforming growth factor- $\beta 1$ : Contrasting effects on resting and activated macrophages. J Leuk Biol 57: 919928.

Allinen M, Beroukhim R, Cai L, Brennan C, Lahti-Domenici J, Huang H, Porter D, Hu M, Chin L, Richardson A et al. 2004. Molecular characterization of the tumor microenvironment in breast cancer. Cancer Cell 6: 17-32.

Anido J, Saez-Borderias A, Gonzalez-Junca A, Rodón L, Folch G, Carmona MA, Prieto-Sanchez RM, Barba I, Martinez-Saez E, Prudkin L, et al. 2010. TGF- $\beta$ receptor inhibitors target the CD $44^{\text {high }} / \mathrm{Id} 1^{\text {high }}$ glioma-initiating cell population in human glioblastoma. Cancer Cell 18: 655-668.

Aragón E, Goerner N, Zaromytidou AI, Xi Q, Escobedo A, Massagué J, Macias MJ. 2011. A Smad action turnover switch operated by WW domain readers of a phosphoserine code. Genes Dev 25: 1275-1288.

Arnal-Estapé A, Tarragona M, Morales M, Guiu M, Nadal C, Massagué J, Gomis RR. 2010. HER2 silences tumor suppression in breast cancer cells by switching expression of C/EBP $\beta$ isoforms. Cancer Res 70: 9927-9936.

Arteaga CL, Hurd SD, Winnier AR, Johnson MD, Fendly BM, Forbes JT. 1993. Anti-transforming growth factor (TGF)- $\beta$ antibodies inhibit breast cancer cell tumorigenicity and increase mouse spleen natural killer cell activity. Implications for a possible role of tumor cell/host TGF- $\beta$ interactions in human breast cancer progression. J Clin Invest 92: 2569-2576.

Arteaga CL, Koli KM, Dugger TC, Clarke R. 1999. Reversal of tamoxifen resistance of human breast carcinomas in vivo by neutralizing antibodies to transforming growth factor- $\beta$. J Natl Cancer Inst 91: 46-53.

Attisano L, Wrana JL, Cheifetz S, Massagué J. 1992. Nove activin receptors: Distinct genes and alternative mRNA splicing generate a repertoire of serine/threonine kinase receptors. Cell 68: 97-108.

Baccelli I, Schneeweiss A, Riethdorf S, Stenzinger A, Schillert A, Vogel V, Klein C, Saini M, Bauerle T, Wallwiener M, et al. 2013. Identification of a population of blood circulating tumor cells from breast cancer patients that initiates metastasis in a xenograft assay. Nat Biotechnol 31: 539544. 
J. Seoane and R.R. Gomis

Bardeesy N, Cheng KH, Berger JH, Chu GC, Pahler J, Olson P, Hezel AF, Horner J, Lauwers GY, Hanahan D, et al. 2006. Smad4 is dispensable for normal pancreas development yet critical in progression and tumor biology of pancreas cancer. Genes Dev 20: 3130-3146.

Barrett MT, Schutte M, Kern SE, Reid BJ. 1996. Allelic loss and mutational analysis of the DPC4 gene in esophageal adenocarcinoma. Cancer Res 56: 4351-4353.

Bauer M, Su G, Casper C, He R, Rehrauer W, Friedl A. 2010. Heterogeneity of gene expression in stromal fibroblasts of human breast carcinomas and normal breast. Oncogene 29: $1732-1740$.

Bhowmick NA, Moses HL. 2005. Tumor-stroma interactions. Curr Opin Genet Dev 15: 97-101.

Bhowmick NA, Chytil A, Plieth D, Gorska AE, Dumont N, Shappell S, Washington MK, Neilson EG, Moses HL. 2004. TGF- $\beta$ signaling in fibroblasts modulates the oncogenic potential of adjacent epithelia. Science 303: 848 851.

Bierie B, Moses HL. 2006. Tumour microenvironment TGF $\beta$ : The molecular Jekyll and Hyde of cancer. Nat Rev Cancer 6: 506-520.

Biswas S, Guix M, Rinehart C, Dugger TC, Chytil A, Moses HL, Freeman ML, Arteaga CL. 2007. Inhibition of TGF- $\beta$ with neutralizing antibodies prevents radiation-induced acceleration of metastatic cancer progression. J Clin Invest 117: 1305-1313.

Broderick P, Carvajal-Carmona L, Pittman AM, Webb E, Howarth K, Rowan A, Lubbe S, Spain S, Sullivan K, Fielding S, et al. 2007. A genome-wide association study shows that common alleles of SMAD7 influence colorectal cancer risk. Nat Genet 39: 1315-1317.

Bruna A, Darken RS, Rojo F, Ocana A, Peñuelas S, Arias A, Paris R, Tortosa A, Mora J, Baselga J, et al. 2007. High TGF $\beta$-Smad activity confers poor prognosis in glioma patients and promotes cell proliferation depending on the methylation of the PDGF-B gene. Cancer Cell 11: $147-160$.

Buck MB, Fritz P, Dippon J, Zugmaier G, Knabbe C. 2004. Prognostic significance of transforming growth factor $\beta$ receptor II in estrogen receptor-negative breast cancer patients. Clin Cancer Res 10: 491-498.

Calon A, Espinet E, Palomo-Ponce S, Tauriello DV, Iglesias M, Cespedes MV, Sevillano M, Nadal C, Jung P, Zhang $\mathrm{XH}$, et al. 2012. Dependency of colorectal cancer on a TGF- $\beta$-driven program in stromal cells for metastasis initiation. Cancer Cell 22: 571-584.

Calon A, Lonardo E, Berenguer-Llergo A, Espinet E, Hernando-Momblona X, Iglesias M, Sevillano M, PalomoPonce S, Tauriello DV, Byrom D, et al. 2015. Stromal gene expression defines poor-prognosis subtypes in colorectal cancer. Nat Genet 47: 320-329.

Camenisch TD, Molin DG, Person A, Runyan RB, Gittenberger-de Groot AC, McDonald JA, Klewer SE. 2002. Temporal and distinct TGF $\beta$ ligand requirements during mouse and avian endocardial cushion morphogenesis. Dev Biol 248: 170-181.

Capparelli C, Chiavarina B, Whitaker-Menezes D, Pestell TG, Pestell RG, Hulit J, Ando S, Howell A, MartinezOutschoorn UE, Sotgia F, et al. 2012a. CDK inhibitors (p16/p19/p21) induce senescence and autophagy in cancer-associated fibroblasts, "fueling" tumor growth via paracrine interactions, without an increase in neoangiogenesis. Cell Cycle 11: 3599-3610.

Capparelli C, Guido C, Whitaker-Menezes D, Bonuccelli G, Balliet R, Pestell TG, Goldberg AF, Pestell RG, Howell A, Sneddon S, et al. 2012b. Autophagy and senescence in cancer-associated fibroblasts metabolically supports tumor growth and metastasis via glycolysis and ketone production. Cell Cycle 11: 2285-2302.

Capparelli C, Whitaker-Menezes D, Guido C, Balliet R, Pestell TG, Howell A, Sneddon S, Pestell RG, Martinez-Outschoorn U, Lisanti MP, et al. 2012c. CTGF drives autophagy, glycolysis and senescence in cancer-associated fibroblasts via HIF1 activation, metabolically promoting tumor growth. Cell Cycle 11: 2272-2284.

Carapito R, Bahram S. 2015. Genetics, genomics, and evolutionary biology of NKG2D ligands. Immunol Rev 267: $88-116$.

Castriconi R, Cantoni C, Della Chiesa M, Vitale M, Marcenaro E, Conte R, Biassoni R, Bottino C, Moretta L, Moretta A. 2003. Transforming growth factor $\beta 1$ inhibits expression of NKp30 and NKG2D receptors: Consequences for the NK-mediated killing of dendritic cells. Proc Natl Acad Sci 100: 4120-4125.

Castriconi R, Dondero A, Bellora F, Moretta L, Castellano A, Locatelli F, Corrias MV, Moretta A, Bottino C. 2013. Neuroblastoma-derived TGF- $\beta 1$ modulates the chemokine receptor repertoire of human resting NK cells. J Immunol 190: $5321-5328$.

Cerutti JM, Ebina KN, Matsuo SE, Martins L, Maciel RM, Kimura ET. 2003. Expression of Smad4 and Smad7 in human thyroid follicular carcinoma cell lines. J Endocrinol Invest 26: 516-521.

Chen T, Carter D, Garrigue-Antar L, Reiss M. 1998. Transforming growth factor $\beta$ type I receptor kinase mutant associated with metastatic breast cancer. Cancer Res 58: 4805-4810.

Chen CR, Kang Y, Siegel PM, Massagué J. 2002. E2F4/5 and p107 as Smad cofactors linking the TGF $\beta$ receptor to cmyc repression. Cell 110: 19-32.

Chen W, Jin W, Hardegen N, Lei KJ, Li L, Marinos N, McGrady G, Wahl SM. 2003. Conversion of peripheral $\mathrm{CD} 4^{+} \mathrm{CD} 25^{-}$naive $\mathrm{T}$ cells to $\mathrm{CD} 4^{+} \mathrm{CD} 25^{+}$regulatory T cells by TGF- $\beta$ induction of transcription factor Foxp3. J Exp Med 198: 1875-1886.

Chen HB, Rud JG, Lin K, Xu L. 2005a. Nuclear targeting of transforming growth factor- $\beta$-activated Smad complexes. J Biol Chem 280: 21329-21336.

Chen ML, Pittet MJ, Gorelik L, Flavell RA, Weissleder R, von Boehmer H, Khazaie K. 2005b. Regulatory T cells suppress tumor-specific CD8 T cell cytotoxicity through TGF- $\beta$ signals in vivo. Proc Natl Acad Sci 102: 419-424.

Cheng N, Chytil A, Shyr Y, Joly A, Moses HL. 2008. Transforming growth factor- $\beta$ signaling-deficient fibroblasts enhance hepatocyte growth factor signaling in mammary carcinoma cells to promote scattering and invasion. $\mathrm{Mol}$ Cancer Res 6: 1521-1533.

Choi SH, Nam JK, Kim BY, Jang J, Jin YB, Lee HJ, Park S, Ji YH, Cho J, Lee YJ. 2016. HSPB1 inhibits the endothelialto-mesenchymal transition to suppress pulmonary fibrosis and lung tumorigenesis. Cancer Res 76:1019-1030.

Dalal BI, Keown PA, Greenberg AH. 1993. Immunocytochemical localization of secreted transforming growth 
factor- $\beta 1$ to the advancing edges of primary tumors and to lymph node metastases of human mammary carcinoma. Am J Pathol 143: 381-389.

David CJ, Huang YH, Chen M, Su J, Zou Y, Bardeesy N, Iacobuzio-Donahue CA, Massagué J. 2016. TGF- $\beta$ tumor suppression through a lethal EMT. Cell 164: 1015-1030.

de Boeck M, Cui C, Mulder AA, Jost CR, Ikeno S, Ten Dijke P. 2016. Smad6 determines BMP-regulated invasive behaviour of breast cancer cells in a zebrafish xenograft model. Sci Rep 6: 24968.

De Wever O, Mareel M. 2003. Role of tissue stroma in cancer cell invasion. J Pathol 200: 429-447.

Del Pozo Martin Y, Park D, Ramachandran A, Ombrato L, Calvo F, Chakravarty P, Spencer-Dene B, Derzsi S, Hill CS, Sahai E, et al. 2015. Mesenchymal cancer cell-stroma crosstalk promotes niche activation, epithelial reversion, and metastatic colonization. Cell Rep 13: 2456-2469.

Derynck R, Zhang YE. 2003. Smad-dependent and Smadindependent pathways in TGF- $\beta$ family signalling. $\mathrm{Na}$ ture 425: 577-584.

Derynck R, Akhurst RJ. 2007. Differentiation plasticity regulated by TGF- $\beta$ family proteins in development and disease. Nat Cell Biol 9: 1000-1004.

Derynck R, Akhurst RJ, Balmain A. 2001. TGF- $\beta$ signaling in tumor suppression and cancer progression. Nat Genet 29: $117-129$.

Derynck R, Muthusamy BP, Saeteurn KY. 2014. Signaling pathway cooperation in TGF- $\beta$-induced epithelial-mesenchymal transition. Curr Opin Cell Biol 31: 56-66.

Diebold RJ, Eis MJ, Yin M, Ormsby I, Boivin GP, Darrow BJ, Saffitz JE, Doetschman T. 1995. Early-onset multifocal inflammation in the transforming growth factor $\beta 1$ null mouse is lymphocyte mediated. Proc Natl Acad Sci 92: 12215-12219.

Ding W, Mouzaki M, You H, Laird JC, Mato J, Lu SC, Rountree CB. 2009. CD133 ${ }^{+}$liver cancer stem cells from methionine adenosyl transferase $1 \mathrm{~A}$-deficient mice demonstrate resistance to transforming growth factor (TGF)- $\beta$ induced apoptosis. Hepatology 49: 1277-1286.

Dowdy SC, Mariani A, Reinholz MM, Keeney GL, Spelsberg TC, Podratz KC, Janknecht R. 2005. Overexpression of the TGF- $\beta$ antagonist Smad7 in endometrial cancer. $G y$ necol Oncol 96: 368-373.

Eichhorn PJ, Rodón L, Gonzalez-Junca A, Dirac A, Gili M, Martinez-Saez E, Aura C, Barba I, Peg V, Prat A, et al. 2012. USP15 stabilizes TGF- $\beta$ receptor I and promotes oncogenesis through the activation of TGF- $\beta$ signaling in glioblastoma. Nat Med 18: 429-435.

Eisenberg LM, Markwald RR. 1995. Molecular regulation of atrioventricular valvuloseptal morphogenesis. Circ Res 77: $1-6$.

Erez N, Truitt M, Olson P, Arron ST, Hanahan D. 2010. Cancer-associated fibroblasts are activated in incipient neoplasia to orchestrate tumor-promoting inflammation in an NF-кB-dependent manner. Cancer Cell 17: 135147.

Feng XH, Derynck R. 2005. Specificity and versatility in TGF- $\beta$ signaling through Smads. Annu Rev Cell Dev Biol 21: 659-693.

Feng XH, Zhang Y, Wu RY, Derynck R. 1998. The tumor suppressor Smad4/DPC4 and transcriptional adaptor
$\mathrm{CBP} / \mathrm{p} 300$ are coactivators for Smad3 in TGF- $\beta$-induced transcriptional activation. Genes Dev 12: 2153-2163.

Fontana A, Constam DB, Frei K, Malipiero U, Pfister HW. 1992. Modulation of the immune response by transforming growth factor $\beta$. Intern Arch Allergy Immunol 99: 1-7.

Forrester E, Chytil A, Bierie B, Aakre M, Gorska AE, SharifAfshar AR, Muller WJ, Moses HL. 2005. Effect of conditional knockout of the type II TGF- $\beta$ receptor gene in mammary epithelia on mammary gland development and polyomavirus middle $\mathrm{T}$ antigen induced tumor formation and metastasis. Cancer Res 65: 2296-2302.

Fournier PG, Juarez P, Jiang G, Clines GA, Niewolna M, Kim HS, Walton HW, Peng XH, Liu Y, Mohammad KS, et al. 2015. The TGF- $\beta$ signaling regulator PMEPA1 suppresses prostate cancer metastases to bone. Cancer Cell 27: 809821.

Franco DL, Mainez J, Vega S, Sancho P, Murillo MM, de Frutos CA, Del Castillo G, Lopez-Blau C, Fabregat I, Nieto MA. 2010. Snaill suppresses TGF- $\beta$-induced apoptosis and is sufficient to trigger EMT in hepatocytes. J Cell Sci 123: 3467-3477.

Franklin CC, Rosenfeld-Franklin ME, White C, Kavanagh TJ, Fausto N. 2003. TGF $\beta 1$-induced suppression of glutathione antioxidant defenses in hepatocytes: Caspasedependent post-translational and caspase-independent transcriptional regulatory mechanisms. FASEB J 17: 1535-1537.

Franzén P, ten Dijke P, Ichijo H, Yamashita H, Schulz P, Heldin CH, Miyazono K. 1993. Cloning of a TGF $\beta$ type I receptor that forms a heteromeric complex with the TGF $\beta$ type II receptor. Cell 75: 681-692.

Friedl P, Locker J, Sahai E, Segall JE. 2012. Classifying collective cancer cell invasion. Nat Cell Biol 14: 777-783.

Friedman E, Gold LI, Klimstra D, Zeng ZS, Winawer S, Cohen A. 1995. High levels of transforming growth factor $\beta 1$ correlate with disease progression in human colon cancer. Cancer Epidemiol Biomarkers Prev 4: 549-554.

Fruman DA, Rommel C. 2014. PI3K and cancer: Lessons, challenges and opportunities. Nat Rev Drug Discov 13: $140-156$.

Fuentealba LC, Eivers E, Ikeda A, Hurtado C, Kuroda H, Pera EM, De Robertis EM. 2007. Integrating patterning signals: Wnt/GSK3 regulates the duration of the BMP/ Smad1 signal. Cell 131: 980-993.

Gallione C, Aylsworth AS, Beis J, Berk T, Bernhardt B, Clark RD, Clericuzio C, Danesino C, Drautz J, Fahl J, et al. 2010. Overlapping spectra of SMAD4 mutations in juvenile polyposis (JP) and JP-HHT syndrome. Am J Med Genet A 152A: 333-339.

Gao S, Alarcón C, Sapkota G, Rahman S, Chen PY, Goerner $\mathrm{N}$, Macias MJ, Erdjument-Bromage H, Tempst P, Massagué J. 2009. Ubiquitin ligase Nedd4L targets activated Smad2/ 3 to limit TGF- $\beta$ signaling. Mol Cell 36: $457-$ 468.

Gao H, Chakraborty G, Lee-Lim AP, Mo Q, Decker M, Vonica A, Shen R, Brogi E, Brivanlou AH, Giancotti FG. 2012. The BMP inhibitor Coco reactivates breast cancer cells at lung metastatic sites. Cell 150: 764-779.

Geiser AG, Letterio JJ, Kulkarni AB, Karlsson S, Roberts AB, Sporn MB. 1993. Transforming growth factor $\beta 1$ (TGF$\beta 1$ ) controls expression of major histocompatibility genes in the postnatal mouse: Aberrant histocompatibil- 
J. Seoane and R.R. Gomis

ity antigen expression in the pathogenesis of the TGF- $\beta 1$ null mouse phenotype. Proc Natl Acad Sci 90: 99449948.

Ghiringhelli F, Menard C, Terme M, Flament C, Taieb J, Chaput N, Puig PE, Novault S, Escudier B, Vivier E, et al. 2005. $\mathrm{CD} 4^{+} \mathrm{CD} 25^{+}$regulatory $\mathrm{T}$ cells inhibit natural killer cell functions in a transforming growth factor- $\beta$ dependent manner. J Exp Med 202: 1075-1085.

Goggins M, Shekher M, Turnacioglu K, Yeo CJ, Hruban RH, Kern SE. 1998. Genetic alterations of the transforming growth factor $\beta$ receptor genes in pancreatic and biliary adenocarcinomas. Cancer Res 58: 5329-5332.

Gold LI. 1999. The role for transforming growth factor- $\beta$ (TGF- $\beta$ ) in human cancer. Crit Rev Oncog 10: 303-360.

Gomis RR, Alarcón C, He W, Wang Q, Seoane J, Lash A, Massagué J. 2006a. A FoxO-Smad synexpression group in human keratinocytes. Proc Natl Acad Sci 103: 1274712752.

Gomis RR, Alarcón C, Nadal C, Van Poznak C, Massagué J. 2006b. C/EBP $\beta$ at the core of the TGF $\beta$ cytostatic response and its evasion in metastatic breast cancer cells. Cancer Cell 10: 203-214.

Gorelik L, Flavell RA. 2001. Immune-mediated eradication of tumors through the blockade of transforming growth factor- $\beta$ signaling in T cells. Nat Med 7: 1118-1122.

Goto K, Kamiya Y, Imamura T, Miyazono K, Miyazawa K. 2007. Selective inhibitory effects of Smad6 on bone morphogenetic protein type I receptors. J Biol Chem 282: 20603-20611.

Grady WM, Myeroff LL, Swinler SE, Rajput A, Thiagalingam S, Lutterbaugh JD, Neumann A, Brattain MG, Chang J, Kim SJ, et al. 1999. Mutational inactivation of transforming growth factor $\beta$ receptor type II in microsatellite stable colon cancers. Cancer Res 59: 320-324.

Guise TA, Yin JJ, Taylor SD, Kumagai Y, Dallas M, Boyce BF, Yoneda T, Mundy GR. 1996. Evidence for a causal role of parathyroid hormone-related protein in the pathogenesis of human breast cancer-mediated osteolysis. J Clin Invest 98: $1544-1549$.

Gupta GP, Perk J, Acharyya S, de Candia P, Mittal V, Todorova-Manova K, Gerald WL, Brogi E, Benezra R, Massagué J. 2007. ID genes mediate tumor reinitiation during breast cancer lung metastasis. Proc Natl Acad Sci 104: 19506-19511.

Haak-Frendscho M, Wynn TA, Czuprynski CJ, Paulnock D. 1990. Transforming growth factor- $\beta 1$ inhibits activation of macrophage cell line RAW 264.7 for cell killing. Clin Exp Immunol 82: 404-410.

Halder SK, Rachakonda G, Deane NG, Datta PK. 2008. Smad7 induces hepatic metastasis in colorectal cancer. Br J Cancer 99: 957-965.

Hashimoto N, Phan SH, Imaizumi K, Matsuo M, Nakashima H, Kawabe T, Shimokata K, Hasegawa Y. 2010. Endothelial-mesenchymal transition in bleomycin-induced pulmonary fibrosis. Am J Respir Cell Mol Biol 43: $161-172$.

Hawinkels LJ, Verspaget HW, van der Reijden JJ, van der Zon JM, Verheijen JH, Hommes DW, Lamers CB, Sier CF 2009. Active TGF- $\beta 1$ correlates with myofibroblasts and malignancy in the colorectal adenoma-carcinoma sequence. Cancer Sci 100: 663-670.
Herrera B, Alvarez AM, Beltran J, Valdes F, Fabregat I, Fernández M. 2004. Resistance to TGF- $\beta$-induced apoptosis in regenerating hepatocytes. J Cell Physiol 201: 385-392.

Hoodless PA, Haerry T, Abdollah S, Stapleton M, O'Connor MB, Attisano L, Wrana JL. 1996. MADR1, a MAD-related protein that functions in BMP2 signaling pathways. Cell 85: $489-500$.

Howe JR, Bair JL, Sayed MG, Anderson ME, Mitros FA, Petersen GM, Velculescu VE, Traverso G, Vogelstein B. 2001. Germline mutations of the gene encoding bone morphogenetic protein receptor $1 \mathrm{~A}$ in juvenile polyposis. Nat Genet 28: 184-187.

Huber MA, Azoitei N, Baumann B, Grunert S, Sommer A, Pehamberger H, Kraut N, Beug H, Wirth T. 2004. NF- $\kappa B$ is essential for epithelial-mesenchymal transition and metastasis in a model of breast cancer progression. J Clin Invest 114: 569-581.

Huse M, Chen YG, Massagué J, Kuriyan J. 1999. Crystal structure of the cytoplasmic domain of the type I TGF $\beta$ receptor in complex with FKBP12. Cell 96: 425-436.

Huse M, Muir TW, Xu L, Chen YG, Kuriyan J, Massagué J. 2001. The TGF $\beta$ receptor activation process: an inhibitor- to substrate-binding switch. Mol Cell 8: 671-682.

Ikushima H, Todo T, Ino Y, Takahashi M, Miyazawa K, Miyazono K. 2009. Autocrine TGF- $\beta$ signaling maintains tumorigenicity of glioma-initiating cells through Sry-related HMG-box factors. Cell Stem Cell 5: 504-514.

Ito N, Kawata S, Tamura S, Shirai Y, Kiso S, Tsushima H, Matsuzawa Y. 1995. Positive correlation of plasma transforming growth factor- $\beta 1$ levels with tumor vascularity in hepatocellular carcinoma. Cancer Lett 89: 45-48.

Iwano M, Plieth D, Danoff TM, Xue C, Okada H, Neilson EG. 2002. Evidence that fibroblasts derive from epithelium during tissue fibrosis. J Clin Invest 110: 341-350.

Izumoto S, Arita N, Ohnishi T, Hiraga S, Taki T, Tomita N, Ohue M, Hayakawa T. 1997. Microsatellite instability and mutated type II transforming growth factor- $\beta$ receptor gene in gliomas. Cancer Lett 112: 251-256.

Jaffee EM, Hruban RH, Canto M, Kern SE. 2002. Focus on pancreas cancer. Cancer Cell 2: 25-28.

Jang CW, Chen CH, Chen CC, Chen JY, Su YH, Chen RH. 2002. TGF- $\beta$ induces apoptosis through Smad-mediated expression of DAP-kinase. Nat Cell Biol 4: 51-58.

Jennings MT, Pietenpol JA. 1998. The role of transforming growth factor $\beta$ in glioma progression. J Neurooncol 36: 123-140.

Kang Y, Chen CR, Massagué J. 2003a. A self-enabling TGF $\beta$ response coupled to stress signaling: Smad engages stress response factor ATF3 for Id 1 repression in epithelial cells. Mol Cell 11: 915-926.

Kang Y, Siegel PM, Shu W, Drobnjak M, Kakonen SM, Cordon-Cardo C, Guise TA, Massagué J. 2003b. A multigenic program mediating breast cancer metastasis to bone. Cancer Cell 3: 537-549.

Kim BG, Li C, Qiao W, Mamura M, Kasprzak B, Anver M, Wolfraim L, Hong S, Mushinski E, Potter M, et al. 2006. Smad4 signalling in T cells is required for suppression of gastrointestinal cancer. Nature 441: 1015-1019.

Kleeff J, Maruyama H, Friess H, Buchler MW, Falb D, Korc M. 1999. Smad6 suppresses TGF- $\beta$-induced growth inhibition in COLO-357 pancreatic cancer cells and is over- 
expressed in pancreatic cancer. Biochem Biophys Res Commun 255: 268-273.

Kojima Y, Acar A, Eaton EN, Mellody KT, Scheel C, BenPorath I, Onder TT, Wang ZC, Richardson AL, Weinberg RA, et al. 2010. Autocrine TGF- $\beta$ and stromal cell-derived factor-1 (SDF-1) signaling drives the evolution of tumor-promoting mammary stromal myofibroblasts. Proc Natl Acad Sci 107: 20009-20014.

Kontani K, Kajino K, Huangi CL, Fujino S, Taguchi O, Yamauchi A, Yokomise H, Ogasawara K. 2006. Spontaneous elicitation of potent antitumor immunity and eradication of established tumors by administration of DNA encoding soluble transforming growth factor- $\beta$ II receptor without active antigen-sensitization. Cancer Immunol Immunother 55: 579-587.

Korchynskyi O, ten Dijke P. 2002. Identification and functional characterization of distinct critically important bone morphogenetic protein-specific response elements in the Id1 promoter. J Biol Chem 277: 4883-4891.

Kretzschmar M, Liu F, Hata A, Doody J, Massagué J. 1997. The TGF- $\beta$ family mediator Smad1 is phosphorylated directly and activated functionally by the BMP receptor kinase. Genes Dev 11: 984-995.

Kruse PH, Matta J, Ugolini S, Vivier E. 2014. Natural cytotoxicity receptors and their ligands. Immunol Cell Biol 92 221-229.

Kuperwasser C, Chavarria T, Wu M, Magrane G, Gray JW, Carey L, Richardson A, Weinberg RA. 2004. Reconstruction of functionally normal and malignant human breast tissues in mice. Proc Natl Acad Sci 101: 4966-4971.

Lagna G, Hata A, Hemmati-Brivanlou A, Massagué J. 1996. Partnership between DPC4 and Smad proteins in TGF $\beta$ signalling pathways. Nature 383: 832-836.

Lamouille S, Connolly E, Smyth JW, Akhurst RJ, Derynck R. 2012. TGF- $\beta$-induced activation of mTOR complex 2 drives epithelial-mesenchymal transition and cell invasion. J Cell Sci 125: 1259-1273.

Lamouille S, Xu J, Derynck R. 2014. Molecular mechanisms of epithelial-mesenchymal transition. Nat Rev Mol Cell Biol 15: 178-196.

Lang H, Fekete DM. 2001. Lineage analysis in the chicken inner ear shows differences in clonal dispersion for epithelial, neuronal, and mesenchymal cells. Dev Biol 234: $120-137$.

Lee YJ, Han Y, Lu HT, Nguyen V, Qin H, Howe PH, Hocevar BA, Boss JM, Ransohoff RM, Benveniste EN. 1997. TGF$\beta$ suppresses IFN- $\gamma$ induction of class II MHC gene expression by inhibiting class II transactivator messenger RNA expression. J Immunol 158: 2065-2075.

Lee JC, Lee KM, Kim DW, Heo DS. 2004. Elevated TGF- $\beta 1$ secretion and down-modulation of NKG2D underlies impaired NK cytotoxicity in cancer patients. J Immunol 172: $7335-7340$

Lei J, Zou TT, Shi YQ, Zhou X, Smolinski KN, Yin J, Souza RF, Appel R, Wang S, Cymes K, et al. 1996. Infrequent DPC4 gene mutation in esophageal cancer, gastric cancer and ulcerative colitis-associated neoplasms. Oncogene 13: $2459-2462$.

Letterio JJ. 2005. TGF- $\beta$ signaling in T cells: Roles in lymphoid and epithelial neoplasia. Oncogene 24: 5701-5712.
Levy L, Hill CS. 2006. Alterations in components of the TGF- $\beta$ superfamily signaling pathways in human cancer. Cytokine Growth Factor Rev 17: 41-58.

Li MO, Flavell RA. 2008. TGF- $\beta$ : A master of all T cell trades. Cell 134: 392-404.

Li MO, Wan YY, Sanjabi S, Robertson AK, Flavell RA. 2006. Transforming growth factor- $\beta$ regulation of immune responses. Annu Rev Immunol 24: 99-146.

Li X, Sterling JA, Fan KH, Vessella RL, Shyr Y, Hayward SW, Matrisian LM, Bhowmick NA. 2012. Loss of TGF- $\beta$ responsiveness in prostate stromal cells alters chemokine levels and facilitates the development of mixed osteoblastic/osteolytic bone lesions. Mol Cancer Res 10: 494-503.

Liebner S, Cattelino A, Gallini R, Rudini N, Iurlaro M, Piccolo S, Dejana E. 2004. $\beta$-Catenin is required for endothelial-mesenchymal transformation during heart cushion development in the mouse. J Cell Biol 166: 359-367.

Lin HY, Wang XF, Ng-Eaton E, Weinberg RA, Lodish HF. 1992. Expression cloning of the TGF- $\beta$ type II receptor, a functional transmembrane serine/threonine kinase. Cell 68: $775-785$.

Lin X, Duan X, Liang YY, Su Y, Wrighton KH, Long J, Hu M, Davis CM, Wang J, Brunicardi FC, et al. 2006. PPM1A functions as a Smad phosphatase to terminate TGF $\beta$ signaling. Cell 125: 915-928.

Liu F, Hata A, Baker JC, Doody J, Carcamo J, Harland RM, Massagué J. 1996. A human Mad protein acting as a BMP-regulated transcriptional activator. Nature 381: 620-623.

Lo RS, Massagué J. 1999. Ubiquitin-dependent degradation of TGF- $\beta$-activated Smad2. Nat Cell Biol 1: 472-478.

Lönn P, van der Heide LP, Dahl M, Hellman U, Heldin CH, Moustakas A. 2010. PARP-1 attenuates Smad-mediated transcription. Mol Cell 40: 521-532.

Luo K, Lodish HF. 1997. Positive and negative regulation of type II TGF- $\beta$ receptor signal transduction by autophosphorylation on multiple serine residues. $E M B O J \mathbf{1 6}$ : 1970-1981.

Luo K, Stroschein SL, Wang W, Chen D, Martens E, Zhou S, Zhou Q. 1999. The Ski oncoprotein interacts with the Smad proteins to repress TGF $\beta$ signaling. Genes Dev 13: 2196-2206.

Ma D, Niederkorn JY. 1995. Transforming growth factor- $\beta$ down-regulates major histocompatibility complex class I antigen expression and increases the susceptibility of uveal melanoma cells to natural killer cell-mediated cytolysis. Immunology 86: 263-269.

Macias MJ, Martin-Malpartida P, Massagué J. 2015. Structural determinants of Smad function in TGF- $\beta$ signaling. Trends Biochem Sci 40: 296-308.

Malanchi I, Santamaria-Martinez A, Susanto E, Peng H, Lehr HA, Delaloye JF, Huelsken J. 2012. Interactions between cancer stem cells and their niche govern metastatic colonization. Nature 481: 85-89.

Mani SA, Guo W, Liao MJ, Eaton EN, Ayyanan A, Zhou AY, Brooks M, Reinhard F, Zhang CC, Shipitsin M, et al. 2008. The epithelial-mesenchymal transition generates cells with properties of stem cells. Cell 133: 704-715.

Maric C, Ryan GB, Alcorn D. 1997. Embryonic and postnatal development of the rat renal interstitium. Anat Embryol (Berl) 195: 503-514. 
Markowitz S, Wang J, Myeroff L, Parsons R, Sun L, Lutterbaugh J, Fan RS, Zborowska E, Kinzler KW, Vogelstein B, et al. 1995. Inactivation of the type II TGF- $\beta$ receptor in colon cancer cells with microsatellite instability. Science 268: $1336-1338$.

Massagué J. 2008. TGF $\beta$ in cancer. Cell 134: 215-230.

Massagué J. 2012. TGF $\beta$ signalling in context. Nat Rev Mol Cell Biol 13: 616-630.

Massagué J, Gomis RR. 2006. The logic of TGF $\beta$ signaling. FEBS Lett 580: 2811-2820.

Massagué J, Blain SW, Lo RS. 2000. TGFß signaling in growth control, cancer, and heritable disorders. Cell 103: 295-309.

McDonald PP, Fadok VA, Bratton D, Henson PM. 1999. Transcriptional and translational regulation of inflammatory mediator production by endogenous TGF- $\beta$ in macrophages that have ingested apoptotic cells. J Immunol 163: 6164-6172.

Merlos-Suárez A, Barriga FM, Jung P, Iglesias M, Cespedes MV, Rossell D, Sevillano M, Hernando-Momblona X, da Silva-Diz V, Munoz P, et al. 2011. The intestinal stem cell signature identifies colorectal cancer stem cells and predicts disease relapse. Cell Stem Cell 8: 511-524.

Miettinen PJ, Ebner R, Lopez AR, Derynck R. 1994. TGF- $\beta$ induced transdifferentiation of mammary epithelial cells to mesenchymal cells: Involvement of type I receptors. J Cell Biol 127: 2021-2036.

Minn AJ, Gupta GP, Siegel PM, Bos PD, Shu W, Giri DD, Viale A, Olshen AB, Gerald WL, Massagué J. 2005. Genes that mediate breast cancer metastasis to lung. Nature 436: $518-524$.

Mohammad KS, Javelaud D, Fournier PG, Niewolna M, McKenna CR, Peng XH, Duong V, Dunn LK, Mauviel A, Guise TA. 2011. TGF- $\beta$-RI kinase inhibitor SD-208 reduces the development and progression of melanoma bone metastases. Cancer Res 71: 175-184.

Moo-Young TA, Larson JW, Belt BA, Tan MC, Hawkins WG, Eberlein TJ, Goedegebuure PS, Linehan DC. 2009. Tumor-derived TGF- $\beta$ mediates conversion of $\mathrm{CD}^{+}{ }^{+} \mathrm{Foxp}^{+}$regulatory $\mathrm{T}$ cells in a murine model of pancreas cancer. J Immunother 32: 12-21.

Moustakas A, Heldin P. 2014. TGF $\beta$ and matrix-regulated epithelial to mesenchymal transition. Biochim Biophys Acta 1840: 2621-2634.

Mu Y, Gudey SK, Landstrom M. 2012. Non-Smad signaling pathways. Cell Tissue Res 347: 11-20.

Mundy GR. 2002. Metastasis to bone: Causes, consequences and therapeutic opportunities. Nat Rev Cancer 2: 584593.

Muraoka RS, Koh Y, Roebuck LR, Sanders ME, BrantleySieders D, Gorska AE, Moses HL, Arteaga CL. 2003. Increased malignancy of Neu-induced mammary tumors overexpressing active transforming growth factor $\beta 1 . \mathrm{Mol}$ Cell Biol 23: 8691-8703.

Naka K, Hoshii T, Muraguchi T, Tadokoro Y, Ooshio T, Kondo Y, Nakao S, Motoyama N, Hirao A. 2010. TGF$\beta-$ FOXO signalling maintains leukaemia-initiating cells in chronic myeloid leukaemia. Nature 463: 676-680.

Naka K, Jomen Y, Ishihara K, Kim J, Ishimoto T, Bae EJ, Mohney RP, Stirdivant SM, Oshima H, Oshima M, et al. 2015. Dipeptide species regulate p38MAPK-Smad3 signalling to maintain chronic myelogenous leukaemia stem cells. Nat Commun 6: 8039.

Navab R, Strumpf D, Bandarchi B, Zhu CQ, Pintilie M, Ramnarine VR, Ibrahimov E, Radulovich N, Leung L, Barczyk M, et al. 2011. Prognostic gene-expression signature of carcinoma-associated fibroblasts in non-smallcell lung cancer. Proc Natl Acad Sci 108: 7160-7165.

Neuzillet C, de Gramont A, Tijeras-Raballand A, de Mestier L, Cros J, Faivre S, Raymond E. 2014. Perspectives of TGF- $\beta$ inhibition in pancreatic and hepatocellular carcinomas. Oncotarget 5: 78-94.

Nguyen DH, Oketch-Rabah HA, Illa-Bochaca I, Geyer FC, Reis-Filho JS, Mao JH, Ravani SA, Zavadil J, Borowsky AD, Jerry DJ, et al. 2011. Radiation acts on the microenvironment to affect breast carcinogenesis by distinct mechanisms that decrease cancer latency and affect tumor type. Cancer Cell 19: 640-651.

Niehrs C, Pollet N. 1999. Synexpression groups in eukaryotes. Nature 402: 483-487.

Novitskiy SV, Forrester E, Pickup MW, Gorska AE, Chytil A, Aakre M, Polosukhina D, Owens P, Yusupova DR, Zhao $Z$, et al. 2014. Attenuated transforming growth factor $\beta$ signaling promotes metastasis in a model of HER2 mammary carcinogenesis. Breast Cancer Res 16: 425.

Ocana OH, Corcoles R, Fabra A, Moreno-Bueno G, Acloque H, Vega S, Barrallo-Gimeno A, Cano A, Nieto MA. 2012. Metastatic colonization requires the repression of the epithelial-mesenchymal transition inducer Prrxl. Cancer Cell 22: 709-724.

Oft M, Peli J, Rudaz C, Schwarz H, Beug H, Reichmann E. 1996. TGF- $\beta 1$ and Ha-Ras collaborate in modulating the phenotypic plasticity and invasiveness of epithelial tumor cells. Genes Dev 10: 2462-2477.

Oft M, Akhurst RJ, Balmain A. 2002. Metastasis is driven by sequential elevation of H-ras and Smad2 levels. Nat Cell Biol 4: 487-494.

Ogino S, Kawasaki T, Ogawa A, Kirkner GJ, Loda M, Fuchs CS. 2007. TGFBR2 mutation is correlated with CpG island methylator phenotype in microsatellite instabilityhigh colorectal cancer. Hum Pathol 38: 614-620.

Ohgushi M, Kuroki S, Fukamachi H, O’Reilly LA, Kuida K, Strasser A, Yonehara S. 2005. Transforming growth factor $\beta$-dependent sequential activation of Smad, Bim, and caspase-9 mediates physiological apoptosis in gastric epithelial cells. Mol Cell Biol 25: 10017-10028.

Ojeda-Fernández L, Recio-Poveda L, Aristorena M, Lastres P, Blanco FJ, Sanz-Rodriguez F, Gallardo-Vara E, de las Casas-Engel M, Corbi A, Arthur HM, et al. 2016. Mice lacking endoglin in macrophages show an impaired immune response. PLoS Genet 12: e1005935.

Orimo A, Gupta PB, Sgroi DC, Arenzana-Seisdedos F, Delaunay T, Naeem R, Carey VJ, Richardson AL, Weinberg RA. 2005. Stromal fibroblasts present in invasive human breast carcinomas promote tumor growth and angiogenesis through elevated SDF-1/CXCL12 secretion. Cell 121: 335-348.

Oskarsson T, Batlle E, Massagué J. 2014. Metastatic stem cells: Sources, niches, and vital pathways. Cell Stem Cell 14: $306-321$.

Ozdamar B, Bose R, Barrios-Rodiles M, Wang HR, Zhang Y, Wrana JL. 2005. Regulation of the polarity protein Par6 
by TGF $\beta$ receptors controls epithelial cell plasticity. Science 307: 1603-1609.

Padua D, Zhang XH, Wang Q, Nadal C, Gerald WL, Gomis RR, Massagué J. 2008. TGF $\beta$ primes breast tumors for lung metastasis seeding through angiopoietin-like 4. Cell 133: 66-77.

Pardali K, Kurisaki A, Morén A, ten Dijke P, Kardassis D, Moustakas A. 2000. Role of Smad proteins and transcription factor Sp1 in p21 Waf1/Cip1 regulation by transforming growth factor- $\beta$. J Biol Chem 275: 29244-29256.

Park JA, Wang E, Kurt RA, Schluter SF, Hersh EM, Akporiaye ET. 1997. Expression of an antisense transforming growth factor- $\beta 1$ transgene reduces tumorigenicity of EMT6 mammary tumor cells. Cancer Gene Ther 4: 42-50.

Pece S, Tosoni D, Confalonieri S, Mazzarol G, Vecchi M, Ronzoni S, Bernard L, Viale G, Pelicci PG, Di Fiore PP. 2010. Biological and molecular heterogeneity of breast cancers correlates with their cancer stem cell content. Cell 140: 62-73.

Peinado H, Quintanilla M, Cano A. 2003. Transforming growth factor $\beta 1$ induces Snail transcription factor in epithelial cell lines: Mechanisms for epithelial mesenchymal transitions. J Biol Chem 278: 21113-21123.

Peñuelas S, Anido J, Prieto-Sanchez RM, Folch G, Barba I, Cuartas I, Garcia-Dorado D, Poca MA, Sahuquillo J, Baselga J, et al. 2009. TGF- $\beta$ increases glioma-initiating cell self-renewal through the induction of LIF in human glioblastoma. Cancer Cell 15: 315-327.

Perlman R, Schiemann WP, Brooks MW, Lodish HF, Weinberg RA. 2001. TGF- $\beta$-induced apoptosis is mediated by the adapter protein Daxx that facilitates JNK activation. Nat Cell Biol 3: 708-714.

Petersen OW, Nielsen HL, Gudjonsson T, Villadsen R, Rank F, Niebuhr E, Bissell MJ, Ronnov-Jessen L. 2003. Epithelial to mesenchymal transition in human breast cancer can provide a nonmalignant stroma. Am J Pathol 162: 391-402.

Petritsch C, Beug H, Balmain A, Oft M. 2000. TGF- $\beta$ inhibits p70 S6 kinase via protein phosphatase $2 A$ to induce $G_{1}$ arrest. Genes Dev 14: 3093-3101.

Polyak K, Weinberg RA. 2009. Transitions between epithelial and mesenchymal states: Acquisition of malignant and stem cell traits. Nat Rev Cancer 9: 265-273.

Portella G, Cumming SA, Liddell J, Cui W, Ireland H, Akhurst RJ, Balmain A. 1998. Transforming growth factor $\beta$ is essential for spindle cell conversion of mouse skin carcinoma in vivo: Implications for tumor invasion. Cell Growth Differ 9: 393-404.

Ramesh S, Qi XJ, Wildey GM, Robinson J, Molkentin J, Letterio J, Howe PH. 2008. TGF $\beta$-mediated BIM expression and apoptosis are regulated through SMAD3-dependent expression of the MAPK phosphatase MKP2. EMBO Rep 9: 990-997.

Ramjaun AR, Tomlinson S, Eddaoudi A, Downward J. 2007. Upregulation of two $\mathrm{BH} 3$-only proteins, Bmf and Bim, during TGF $\beta$-induced apoptosis. Oncogene 26: 970-981.

Ranchoux B, Antigny F, Rucker-Martin C, Hautefort A, Pechoux C, Bogaard HJ, Dorfmuller P, Remy S, Lecerf F, Plante S, et al. 2015. Endothelial-to-mesenchymal transition in pulmonary hypertension. Circulation 131: 1006-1018.
Ranges GE, Figari IS, Espevik T, Palladino MA Jr. 1987. Inhibition of cytotoxic $\mathrm{T}$ cell development by transforming growth factor $\beta$ and reversal by recombinant tumor necrosis factor $\alpha$. J Exp Med 166: 991-998.

Roberts AB, Wakefield LM. 2003. The two faces of transforming growth factor $\beta$ in carcinogenesis. Proc Natl Acad Sci 100: 8621-8623.

Rodgarkia-Dara C, Vejda S, Erlach N, Losert A, Bursch W, Berger W, Schulte-Hermann R, Grusch M. 2006. The activin axis in liver biology and disease. Mutat Res 613: $123-137$.

Rodón L, Gonzalez-Junca A, Inda Mdel M, Sala-Hojman A, Martinez-Saez E, Seoane J. 2014. Active CREB1 promotes a malignant TGF $\beta 2$ autocrine loop in glioblastoma. Cancer Disc 4: 1230-1241.

Ruzinova MB, Benezra R. 2003. Id proteins in development, cell cycle and cancer. Trends Cell Biol 13: 410-418.

Sakurai T, Kudo M. 2011. Signaling pathways governing tumor angiogenesis. Oncology 81: 24-29.

Sanchez A, Alvarez AM, Benito M, Fabregat I. 1996. Apoptosis induced by transforming growth factor- $\beta$ in fetal hepatocyte primary cultures: Involvement of reactive oxygen intermediates. J Biol Chem 271: 7416-7422.

Sapkota G, Knockaert M, Alarcón C, Montalvo E, Brivanlou AH, Massagué J. 2006. Dephosphorylation of the linker regions of Smad 1 and Smad2/3 by small C-terminal domain phosphatases has distinct outcomes for bone morphogenetic protein and transforming growth factor- $\beta$ pathways. J Biol Chem 281: 40412-40419.

Sapkota G, Alarcón C, Spagnoli FM, Brivanlou AH, Massagué J. 2007. Balancing BMP signaling through integrated inputs into the Smad1 linker. Mol Cell 25: 441-454.

Scandura JM, Boccuni P, Massagué J, Nimer SD. 2004. Transforming growth factor $\beta$-induced cell cycle arrest of human hematopoietic cells requires p57KIP2 up-regulation. Proc Natl Acad Sci 101: 15231-15236.

Scheel C, Eaton EN, Li SH, Chaffer CL, Reinhardt F, Kah KJ, Bell G, Guo W, Rubin J, Richardson AL, et al. 2011. Paracrine and autocrine signals induce and maintain mesenchymal and stem cell states in the breast. Cell 145: $926-$ 940.

Schmierer B, Hill CS. 2005. Kinetic analysis of Smad nucleocytoplasmic shuttling reveals a mechanism for transforming growth factor $\beta$-dependent nuclear accumulation of Smads. Mol Cell Biol 25: 9845-9858.

Schwenter F, Faughnan ME, Gradinger AB, Berk T, Gryfe R, Pollett A, Cohen Z, Gallinger S, Durno C. 2012. Juvenile polyposis, hereditary hemorrhagic telangiectasia, and early onset colorectal cancer in patients with SMAD4 mutation. J Gastroenterol 47: 795-804.

Seoane J. 2006. Escaping from the TGF $\beta$ anti-proliferative control. Carcinogenesis 27: 2148-2156.

Seoane J, Le HV, Massagué J. 2002. Myc suppression of the $p 21^{\text {Cip } 1} \mathrm{Cdk}$ inhibitor influences the outcome of the p53 response to DNA damage. Nature 419: 729-734.

Seoane J, Pouponnot C, Staller P, Schader M, Eilers M, Massagué J. 2001. TGF $\beta$ influences Myc, Miz-1 and Smad to control the CDK inhibitor $\mathrm{p} 15^{\mathrm{INK} 4 \mathrm{~b}}$. Nat Cell Biol 3: 400 408.

Seoane J, Le HV, Shen L, Anderson SA, Massagué J. 2004. Integration of Smad and forkhead pathways in the con- 
trol of neuroepithelial and glioblastoma cell proliferation. Cell 117: 211-223.

Sethi N, Dai X, Winter CG, Kang Y. 2011. Tumor-derived Jagged1 promotes osteolytic bone metastasis of breast cancer by engaging notch signaling in bone cells. Cancer Cell 19: 192-205.

Shi Y, Massagué J. 2003. Mechanisms of TGF- $\beta$ signaling from cell membrane to the nucleus. Cell 113: 685-700.

Shi Y, Wang YF, Jayaraman L, Yang H, Massagué J, Pavletich N. 1998. Crystal structure of a Smad MH1 domain bound to DNA: Insights on DNA-binding in TGF- $\beta$ signaling. Cell 94: 585-594.

Shibahara K, Ota M, Horiguchi M, Yoshinaga K, Melamed J, Rifkin DB. 2013. Production of gastrointestinal tumors in mice by modulating latent TGF- $\beta 1$ activation. Cancer Res 73: 459-468.

Shibuya H, Yamaguchi K, Shirakabe K, Tonegawa A, Gotoh Y, Ueno N, Irie K, Nishida E, Matsumoto K. 1996. TAB1: An activator of the TAK1 MAPKKK in TGF- $\beta$ signal transduction. Science 272: 1179-1182.

Shima K, Morikawa T, Yamauchi M, Kuchiba A, Imamura Y, Liao X, Meyerhardt JA, Fuchs CS, Ogino S. 2011. TGFBR2 and BAX mononucleotide tract mutations, microsatellite instability, and prognosis in 1072 colorectal cancers. PLoS ONE 6: e25062.

Shipitsin M, Campbell LL, Argani P, Weremowicz S, Bloushtain-Qimron N, Yao J, Nikolskaya T, Serebryiskaya T, Beroukhim R, Hu M, et al. 2007. Molecular definition of breast tumor heterogeneity. Cancer Cell 11: 259-273.

Shukla A, Edwards R, Yang Y, Hahn A, Folkers K, Ding J, Padmakumar VC, Cataisson C, Suh KS, Yuspa SH. 2014. CLIC4 regulates TGF- $\beta$-dependent myofibroblast differentiation to produce a cancer stroma. Oncogene 33: 842850.

Shull MM, Ormsby I, Kier AB, Pawlowski S, Diebold RJ, Yin M, Allen R, Sidman C, Proetzel G, Calvin D, et al. 1992. Targeted disruption of the mouse transforming growth factor- $\beta 1$ gene results in multifocal inflammatory disease. Nature 359: 693-699.

Sjöblom T, Jones S, Wood LD, Parsons DW, Lin J, Barber TD, Mandelker D, Leary RJ, Ptak J, Silliman N, et al. 2006. The consensus coding sequences of human breast and colorectal cancers. Science 314: 268-274.

Smyth MJ, Strobl SL, Young HA, Ortaldo JR, Ochoa AC. 1991. Regulation of lymphokine-activated killer activity and pore-forming protein gene expression in human peripheral blood $\mathrm{CD}^{+} \mathrm{T}$ lymphocytes. Inhibition by transforming growth factor- $\beta$. J Immunol 146: 3289-3297.

Smyth MJ, Teng MW, Swann J, Kyparissoudis K, Godfrey DI, Hayakawa Y. 2006. CD $4^{+} \mathrm{CD} 25^{+}$T regulatory cells suppress NK cell-mediated immunotherapy of cancer. J Immunol 176: 1582-1587.

Sneddon JB, Zhen HH, Montgomery K, van de Rijn M, Tward AD, West R, Gladstone H, Chang HY, Morganroth GS, Oro AE, et al. 2006. Bone morphogenetic protein antagonist gremlin 1 is widely expressed by cancer-associated stromal cells and can promote tumor cell proliferation. Proc Natl Acad Sci 103: 14842-14847.

Sorrentino A, Thakur N, Grimsby S, Marcusson A, von Bulow V, Schuster N, Zhang S, Heldin CH, Landstrom M. 2008. The type I TGF- $\beta$ receptor engages TRAF6 to activate TAK1 in a receptor kinase-independent manner. Nat Cell Biol 10: 1199-1207.

Staller P, Peukert K, Kiermaier A, Seoane J, Lukas J, Karsunky H, Moroy T, Bartek J, Massagué J, Hanel F, et al. 2001. Repression of $\mathrm{p} 15^{\mathrm{INK} 4 \mathrm{~b}}$ expression by Myc through association with Miz-1. Nat Cell Biol 3: 392-399.

Stankic M, Pavlovic S, Chin Y, Brogi E, Padua D, Norton L, Massagué J, Benezra R. 2013. TGF- $\beta$-Id1 signaling opposes Twist 1 and promotes metastatic colonization via a mesenchymal-to-epithelial transition. Cell Rep 5: 12281242.

Stroschein SL, Wang W, Zhou S, Zhou Q, Luo K. 1999. Negative feedback regulation of TGF- $\beta$ signaling by the SnoN oncoprotein. Science 286: 771-774.

Stuelten CH, DaCosta Byfield S, Arany PR, Karpova TS, Stetler-Stevenson WG, Roberts AB. 2005. Breast cancer cells induce stromal fibroblasts to express MMP-9 via secretion of TNF- $\alpha$ and TGF- $\beta$. J Cell Sci 118: $2143-$ 2153.

Swarbrick A, Roy E, Allen T, Bishop JM. 2008. Id1 cooperates with oncogenic Ras to induce metastatic mammary carcinoma by subversion of the cellular senescence response. Proc Natl Acad Sci 105: 5402-5407.

Takaku K, Oshima M, Miyoshi H, Matsui M, Seldin MF, Taketo MM. 1998. Intestinal tumorigenesis in compound mutant mice of both Dpc4 (Smad4) and Apc genes. Cell 92: $645-656$.

Takekawa M, Tatebayashi K, Itoh F, Adachi M, Imai K, Saito H. 2002. Smad-dependent GADD $45 \beta$ expression mediates delayed activation of p38 MAP kinase by TGF- $\beta$. EMBO J 21: 6473-6482.

Takumi T, Moustakas A, Lin HY, Lodish HF. 1995. Molecular characterization of a type I serine-threonine kinase receptor for TGF- $\beta$ and activin in the rat pituitary tumor cell line GH3. Exp Cell Res 216: 208-214.

Tang B, Yoo N, Vu M, Mamura M, Nam JS, Ooshima A, Du Z, Desprez PY, Anver MR, Michalowska AM, et al. 2007. Transforming growth factor- $\beta$ can suppress tumorigenesis through effects on the putative cancer stem or early progenitor cell and committed progeny in a breast cancer xenograft model. Cancer Res 67: 8643-8652.

Tarragona M, Pavlovic M, Arnal-Estapé A, Urosevic J, Morales M, Guiu M, Planet E, Gonzalez-Suárez E, Gomis RR. 2012. Identification of NOG as a specific breast cancer bone metastasis-supporting gene. J Biol Chem 287: 21346-21355.

ten Dijke P, Arthur HM. 2007. Extracellular control of TGF $\beta$ signalling in vascular development and disease. Nat Rev Mol Cell Biol 8: 857-869.

Thiery JP. 2003. Epithelial-mesenchymal transitions in development and pathologies. Curr Opin Cell Biol 15: 740746.

Thomas DA, Massagué J. 2005. TGF- $\beta$ directly targets cytotoxic $\mathrm{T}$ cell functions during tumor evasion of immune surveillance. Cancer Cell 8: 369-380.

Thuault S, Valcourt U, Petersen M, Manfioletti G, Heldin $\mathrm{CH}$, Moustakas A. 2006. Transforming growth factor- $\beta$ employs HMGA2 to elicit epithelial-mesenchymal transition. J Cell Biol 174: 175-183.

Travis MA, Sheppard D. 2014. TGF- $\beta$ activation and function in immunity. Annu Rev Immunol 32: 51-82. 
Tsuchida K, Lewis KA, Mathews LS, Vale WW. 1993. Molecular characterization of rat transforming growth factor- $\beta$ type II receptor. Biochem Biophys Res Commun 191: 790795.

Tsushima H, Kawata S, Tamura S, Ito N, Shirai Y, Kiso S, Imai Y, Shimomukai H, Nomura Y, Matsuda Y, et al. 1996. High levels of transforming growth factor $\beta 1$ in patients with colorectal cancer: Association with disease progression. Gastroenterology 110: 375-382.

Valastyan S, Weinberg RA. 2011. Tumor metastasis: Molecular insights and evolving paradigms. Cell 147: 275-292.

van Meeteren LA, ten Dijke P. 2012. Regulation of endothelial cell plasticity by TGF- $\beta$. Cell Tissue Res 347: $177-186$.

Varelas X, Sakuma R, Samavarchi-Tehrani P, Peerani R, Rao BM, Dembowy J, Yaffe MB, Zandstra PW, Wrana JL. 2008. TAZ controls Smad nucleocytoplasmic shuttling and regulates human embryonic stem-cell self-renewal. Nat Cell Biol 10: 837-848.

Varol C, Mildner A, Jung S. 2015. Macrophages: Development and tissue specialization. Annu Rev Immunol 33: 643-675.

Walker RA, Dearing SJ. 1992. Transforming growth factor $\beta 1$ in ductal carcinoma in situ and invasive carcinomas of the breast. Eur J Cancer 28: 641-644.

Wang D, Kanuma T, Mizunuma H, Takama F, Ibuki Y, Wake N, Mogi A, Shitara Y, Takenoshita S. 2000. Analysis of specific gene mutations in the transforming growth factor- $\beta$ signal transduction pathway in human ovarian cancer. Cancer Res 60: 4507-4512.

Wang J, Guan E, Roderiquez G, Calvert V, Alvarez R, Norcross MA. 2001. Role of tyrosine phosphorylation in ligand-independent sequestration of CXCR4 in human primary monocytes-macrophages. J Biol Chem 276: 49236-49243.

Wang J, Yang L, Yang J, Kuropatwinski K, Wang W, Liu XQ, Hauser J, Brattain MG. 2008. Transforming growth factor $\beta$ induces apoptosis through repressing the phosphoinositide 3-kinase/AKT/survivin pathway in colon cancer cells. Cancer Res 68: 3152-3160.

Waning DL, Mohammad KS, Reiken S, Xie W, Andersson DC, John S, Chiechi A, Wright LE, Umanskaya A, Niewolna $M$, et al. 2015. Excess TGF- $\beta$ mediates muscle weakness associated with bone metastases in mice. Nat Med 21: 1262-1271.

Weber KT. 1997. Monitoring tissue repair and fibrosis from a distance. Circulation 96: 2488-2492.

Wellner U, Schubert J, Burk UC, Schmalhofer O, Zhu F, Sonntag A, Waldvogel B, Vannier C, Darling D, zur Hausen A, et al. 2009. The EMT-activator ZEB1 promotes tumorigenicity by repressing stemness-inhibiting microRNAs. Nat Cell Biol 11: 1487-1495.

Wikstrom P, Stattin P, Franck-Lissbrant I, Damber JE, Bergh A. 1998. Transforming growth factor $\beta 1$ is associated with angiogenesis, metastasis, and poor clinical outcome in prostate cancer. Prostate 37: 19-29.

Wipff PJ, Rifkin DB, Meister JJ, Hinz B. 2007. Myofibroblast contraction activates latent TGF- $\beta 1$ from the extracellular matrix. J Cell Biol 179: 1311-1323.

Wolfraim LA, Walz TM, James Z, Fernández T, Letterio JJ. 2004. p $21^{\text {Cip } 1}$ and $\mathrm{p} 27^{\text {Kip } 1}$ act in synergy to alter the sensitivity of naïve T cells to TGF- $\beta$-mediated $G_{1}$ arrest through modulation of IL-2 responsiveness. J Immunol 173: 3093-3102.

Wrana JL, Attisano L, Wieser R, Ventura F, Massagué J. 1994. Mechanism of activation of the TGF- $\beta$ receptor. Nature 370: 341-347.

Wu G, Chen YG, Ozdamar B, Gyuricza CA, Chong PA, Wrana JL, Massagué J, Shi Y. 2000. Structural basis of Smad2 recognition by the Smad anchor for receptor activation. Science 287: 92-97.

Wu JW, Hu M, Chai J, Seoane J, Huse M, Li C, Rigotti DJ, Kyin S, Muir TW, Fairman R, et al. 2001. Crystal structure of a phosphorylated Smad2. Recognition of phosphoserine by the MH2 domain and insights on Smad function in TGF- $\beta$ signaling. Mol Cell 8: 1277-1289.

Xu L, Kang Y, Col S, Massagué J. 2002. Smad2 nucleocytoplasmic shuttling by nucleoporins CAN/Nup214 and Nup153 feeds TGF $\beta$ signaling complexes in the cytoplasm and nucleus. Mol Cell 10: 271-282.

Xu L, Alarcón C, Col S, Massagué J. 2003. Distinct domain utilization by Smad 3 and Smad4 for nucleoporin interaction and nuclear import. J Biol Chem 278: 4256942577.

Xu J, Lamouille S, Derynck R. 2009. TGF- $\beta$-induced epithelial to mesenchymal transition. Cell Res 19: 156172.

Xu J, Acharya S, Sahin O, Zhang Q, Saito Y, Yao J, Wang H, Li

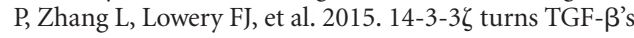
function from tumor suppressor to metastasis promoter in breast cancer by contextual changes of Smad partners from p53 to Gli2. Cancer Cell 27: 177-192.

Yamaguchi K, Shirakabe K, Shibuya H, Irie K, Oishi I, Ueno N, Taniguchi T, Nishida E, Matsumoto K. 1995. Identification of a member of the MAPKKK family as a potential mediator of TGF- $\beta$ signal transduction. Science 270: 2008-2011.

Yamashita M, Fatyol K, Jin C, Wang X, Liu Z, Zhang YE. 2008. TRAF6 mediates Smad-independent activation of JNK and $\mathrm{p} 38$ by TGF- $\beta$. Mol Cell 31: 918-924.

Yang J, Song K, Krebs TL, Jackson MW, Danielpour D. 2008. $\mathrm{Rb} / \mathrm{E} 2 \mathrm{~F} 4$ and Smad2/3 link survivin to TGF- $\beta$-induced apoptosis and tumor progression. Oncogene 27: 53265338.

You H, Ding W, Rountree CB. 2010. Epigenetic regulation of cancer stem cell marker CD133 by transforming growth factor- $\beta$. Hepatology 51: 1635-1644.

Yu M, Bardia A, Wittner BS, Stott SL, Smas ME, Ting DT, Isakoff SJ, Ciciliano JC, Wells MN, Shah AM, et al. 2013. Circulating breast tumor cells exhibit dynamic changes in epithelial and mesenchymal composition. Science 339: 580-584.

Zahnow CA, Younes P, Laucirica R, Rosen JM. 1997. Overexpression of C/EBP $\beta$-LIP, a naturally occurring, dominant-negative transcription factor, in human breast cancer. J Natl Cancer Inst 89: 1887-1891.

Zeisberg EM, Potenta S, Xie L, Zeisberg M, Kalluri R. 2007a. Discovery of endothelial to mesenchymal transition as a source for carcinoma-associated fibroblasts. Cancer Res 67: 10123-10128.

Zeisberg EM, Tarnavski O, Zeisberg M, Dorfman AL, McMullen JR, Gustafsson E, Chandraker A, Yuan X, Pu 
J. Seoane and R.R. Gomis

WT, Roberts AB, et al. 2007b. Endothelial-to-mesenchymal transition contributes to cardiac fibrosis. Nat Med 13: $952-961$.

Zeisberg M, Kalluri R. 2015. Physiology of the renal interstitium. Clin J Am Soc Nephrol 10: 1831-1840.

Zhang YE. 2009. Non-Smad pathways in TGF- $\beta$ signaling. Cell Res 19: 128-139.

Zhang Y, Feng XH, Derynck R. 1998. Smad3 and Smad4 cooperate with c-Jun/c-Fos to mediate TGF- $\beta$-induced transcription. Nature 394: 909-913.

Zhang F, Lee J, Lu S, Pettaway CA, Dong Z. 2005a. Blockade of transforming growth factor- $\beta$ signaling suppresses progression of androgen-independent human prostate cancer in nude mice. Clin Cancer Res 11: 4512-4520.

Zhang Q, Yang X, Pins M, Javonovic B, Kuzel T, Kim SJ, Parijs LV, Greenberg NM, Liu V, Guo Y, et al. 2005b. Adoptive transfer of tumor-reactive transforming growth factor- $\beta$-insensitive CD8 ${ }^{+} \mathrm{T}$ cells: Eradication of autologous mouse prostate cancer. Cancer Res 65: 1761-1769.

Zhang S, Ekman M, Thakur N, Bu S, Davoodpour P, Grimsby S, Tagami S, Heldin CH, Landström M. 2006. TGF $\beta 1$-induced activation of ATM and p53 mediates apoptosis in a Smad7-dependent manner. Cell Cycle 5: 2787-2795.

Zhang M, Kleber S, Rohrich M, Timke C, Han N, Tuettenberg J, Martin-Villalba A, Debus J, Peschke P, Wirkner U, et al. 2011. Blockade of TGF- $\beta$ signaling by the TGF $\beta$ R-I kinase inhibitor LY2109761 enhances radiation response and prolongs survival in glioblastoma. Cancer Res 71: $7155-7167$.

Zhang L, Zhou F, Drabsch Y, Gao R, Snaar-Jagalska BE, Mickanin C, Huang H, Sheppard KA, Porter JA, Lu CX, et al. 2012. USP4 is regulated by AKT phosphorylation and directly deubiquitylates TGF- $\beta$ type I receptor. Nat Cell Biol 14: 717-726.

Zheng X, Carstens JL, Kim J, Scheible M, Kaye J, Sugimoto H, Wu CC, LeBleu VS, Kalluri R. 2015. Epithelial-tomesenchymal transition is dispensable for metastasis but induces chemoresistance in pancreatic cancer. Nature 527: 525-530.

Zhu Q, Krakowski AR, Dunham EE, Wang L, Bandyopadhyay A, Berdeaux R, Martin GS, Sun L, Luo K. 2007. Dual role of SnoN in mammalian tumorigenesis. Mol Cell Biol 27: $324-339$. 


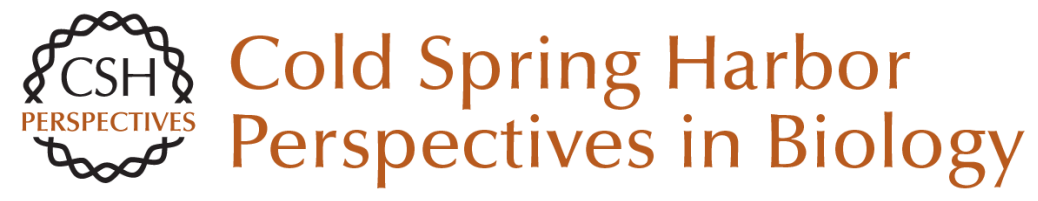

\section{TGF- $\beta$ Family Signaling in Tumor Suppression and Cancer Progression}

Joan Seoane and Roger R. Gomis

Cold Spring Harb Perspect Biol 2017; doi: 10.1101/cshperspect.a022277 originally published online February 28, 2017

Subject Collection The Biology of the TGF-\&\#946; Family

TGF- $\beta$ Family Signaling in Early Vertebrate Development Joseph Zinski, Benjamin Tajer and Mary C. Mullins

Bone Morphogenetic Protein-Based Therapeutic Approaches Jonathan W. Lowery and Vicki Rosen

TGF- $\beta$ Family Signaling in Ductal Differentiation and Branching Morphogenesis

Kaoru Kahata, Varun Maturi and Aristidis Moustakas

TGF- $\beta$ Signaling in Control of Cardiovascular

Function

Marie-José Goumans and Peter ten Dijke

TGF- $\beta$ Family Signaling in Tumor Suppression and Cancer Progression

Joan Seoane and Roger R. Gomis

Targeting TGF- $\beta$ Signaling for Therapeutic Gain Rosemary J. Akhurst

Regulation of Hematopoiesis and Hematological Disease by TGF- $\beta$ Family Signaling Molecules Kazuhito Naka and Atsushi Hirao
TGF- $\beta$ Family Signaling in Mesenchymal

Differentiation

Ingo Grafe, Stefanie Alexander, Jonathan $R$. Peterson, et al.

TGF- $\beta 1$ Signaling and Tissue Fibrosis Kevin K. Kim, Dean Sheppard and Harold A. Chapman

Bone Morphogenetic Proteins in Vascular Homeostasis and Disease Marie-José Goumans, An Zwijsen, Peter ten Dijke, et al.

TGF- $\beta$ Family Signaling in Epithelial

Differentiation and Epithelial-Mesenchymal

Transition

Kaoru Kahata, Mahsa Shahidi Dadras and Aristidis Moustakas

TGF- $\beta$ Family Signaling in Connective Tissue and

Skeletal Diseases

Elena Gallo MacFarlane, Julia Haupt, Harry C. Dietz, et al.

The TGF- $\beta$ Family in the Reproductive Tract Diana Monsivais, Martin M. Matzuk and Stephanie A. Pangas

TGF- $\beta$ Family Signaling in Drosophila Ambuj Upadhyay, Lindsay Moss-Taylor, Myung-Jun Kim, et al.

For additional articles in this collection, see http://cshperspectives.cshlp.org/cgi/collection/

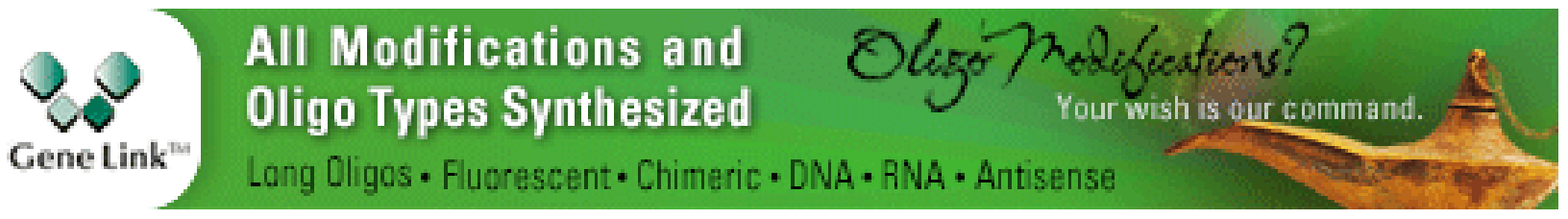


TGF- $\beta$ Family Signaling in Neural and Neuronal Differentiation, Development, and Function Emily A. Meyers and John A. Kessler
Signaling Cross Talk between TGF- $\beta /$ Smad and Other Signaling Pathways Kunxin LuO

For additional articles in this collection, see http://cshperspectives.cshlp.org/cgi/collection/

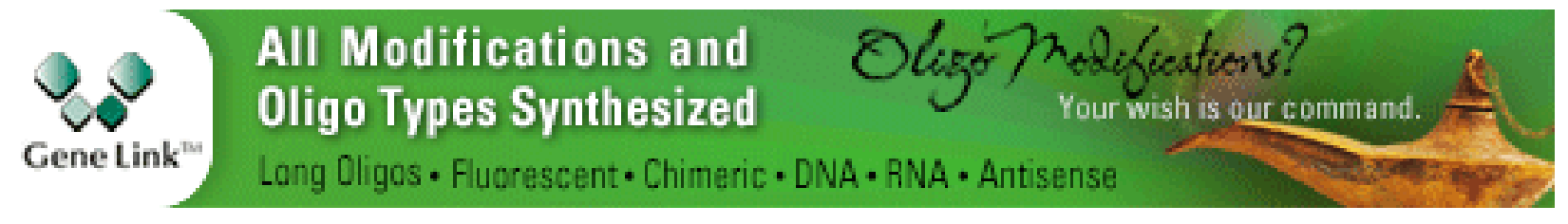

Copyright @ 2017 Cold Spring Harbor Laboratory Press; all rights reserved 